\title{
Design of Biointerfaces for Regenerative Medicine
}

AUTHOR(S):

Arima, Yusuke; Kato, Koichi; Teramura, Yuji; Iwata, Hiroo

\section{CITATION:}

Arima, Yusuke ...[et al]. Design of Biointerfaces for Regenerative Medicine. Advances in Polymer Science 2012, 247: 167-200

\section{ISSUE DATE:}

2012

URL:

http://hdl.handle.net/2433/154891

\section{RIGHT:}

The final publication is available at www.springerlink.com; この論文は 出版社版でありません。引用の際には出版社版をご確認ご利用くださ $\omega_{\circ}$; This is not the published version. Please cite only the published version. 


\section{Design of biointerfaces for regenerative}

\section{medicine}

Yusuke Arima, Koichi Kato, Yuji Teramura, and Hiroo Iwata*

Institute for Frontier Medical Sciences, Kyoto University

53 Kawahara-cho, Sakyo-ku, Shogoin, Kyoto 606-8507, Japan

*To whom correspondence should be addressed. Professor Hiroo Iwata, Institute for Frontier Medical Sciences, Kyoto University, 53 Kawahara-cho, Shogoin, Sakyo-ku, Kyoto 606-8507, Japan.

Tel \& Fax: +81-75-751-4119. E-mail: iwata@frontier.kyoto-u.ac.jp. 


\begin{abstract}
Understanding and controlling biological responses against artificial materials is important for the development of medical devices and therapies. Selfassembled monolayers (SAMs) of alkanethiols provide well-defined surfaces that can be manipulated by varying the terminal functional groups. Thus, SAMs have been extensively used as a platform for studying how artificial materials affect biological responses. Here, we review cell adhesion behavior in response to SAMs with various surface properties and the effects that adsorbed proteins have on subsequent cell adhesion. We also describe an application for SAMs as a substrate for culturing neural stem cells (NSCs). Substrates that induced the correct orientation of immobilized growth factors, like epidermal growth factor (EGF), improved the selection of a pure NSC population during cell expansion. In addition, we review new methodologies for using amphiphilic polymers to modify the surfaces of cells and tissues. Coating the cell surface with amphiphilic polymers that can capture and immobilize bioactive substances or cells represents a promising approach for clinical applications, particularly cellular therapies.
\end{abstract}

\title{
Keywords
}

Self-assembled monolayer, Cell adhesion, Chimeric protein, Stem cell, Islet of Langerhans, Amphiphilic polymer

\section{Contents}

1 Introduction

2 Cell adhesion to a model biomaterial surface

2.1 Self-assembled monolayer as a model surface 
2.2 Cell adhesion on material surfaces

2.3. Effect of protein adsorption on cell adhesion

2.3.1. Amount of protein on a surface

2.3.2. Protein composition on a surface

2.3.3. Protein conformation/orientation on a surface

2.3.4. Cell adhesion in serum free medium

3. Cell culture substrates for specific cell proliferation

3.1. Strategy for adherent cultures of neural stem cells

3.2. Oriented immobilization of engineered epidermal growth factor

3.3. Proliferation of rat NSCs on EGF-His-immobilized surface

3.4. Structural integrity and stability of immobilized EGF-His

3.5. Spontaneously dimerizing EGF

3.6. Modules for culturing NSCs in a closed system

4. Cell surface modifications

4.1. Cell surface modifications with amphiphilic polymers

4.2. Immobilization of bioactive substances on an islet surface

4.3. Encapsulation of islets with living cells

5. Summary

References 


\section{Introduction}

Much effort has been devoted to understanding biological responses to artificial materials $[1,2]$ to facilitate the development of medical devices and artificial organs. However, many issues remain to be fully understood. Furthermore, these studies require overcoming various difficulties, because biological responses are affected by many factors, including surface energy, surface electrostatic properties, macro- and micro-surface morphology, surface heterogeneity, different functional groups, and the mobility of functional groups on surfaces. Systematic studies of biological responses to artificial materials require surfaces with wellcontrolled properties; however, there is a lack of methods for systematically controlling surface properties. Surface chemistry approaches have employed the use of model surfaces, like self-assembled monolayers (SAMs) of alkanethiols, $\mathrm{HS}\left(\mathrm{CH}_{2}\right)_{\mathrm{n}} \mathrm{X}$, where $\mathrm{X}$ denotes various functional groups [3-6]. SAMs are also suitable for studying correlations between biological responses and surface properties.

It has been shown that cell adhesion highly depends on the outermost functional groups on SAMS; however, cells do not directly interact with the SAMs. Instead, they interact with proteins adsorbed on SAMs. Cell adherence requires an interaction between integrin molecules in the cell membrane and glycoproteins specialized for cell adhesion, like fibronectin (Fn) and vitronectin (Vn), which are adsorbed on the artificial material. Thus, the presence of glycoproteins in serum plays a crucial role in cell adherence to artificial materials. In the first part of this review, we will briefly survey recent studies of cell adhesion on SAMs with different functional groups and discuss the mechanisms involved.

Knowledge gained from cell adhesion studies with SAMs has been used to develop culture substrates with the appropriate cell adhesion glycoproteins for different types of cells [7-10]. Stem cells, capable of self-renewal and differentiation into multiple cell types, are found in embryonic and adult tissues. Pluripotent stem cells, like embryonic stem cells and induced pluripotent stem cells, have been developed in vitro. These cells are expected to provide cell sources for regenerative 
medicine. Various culture conditions have been developed to enable expansion of these cells without loss of their multi- and pluripotency and to induce differentiation into viable cells with specific functions.

In the last few years, our group has focused on neural stem cells (NSCs). NSCs were discovered by screening rodent CNS cells for responses to epidermal growth factor (EGF) [11]. Integrin and epidermal growth factor receptor (EGFR) coordinately regulate cell migration, survival, and growth by modulating a common set of signaling pathways. Moreover, EGF was shown to be a mitogen for NSCs. Taking these facts into consideration, we hypothesized that NSCs might be selectively trapped on SAM surfaces through EGF-EGFR interactions, and this interaction might strongly promote NSC proliferation due to EGFR signaling. In the second part of this article, we will describe our own work on cultured NSC interactions with surface-immobilized EGF.

Regenerative medicine and tissue engineering have opened new therapeutic domains. Stem cells have become therapeutic units for generating functional cells and tissues. One of the more successful endeavors has been the transplantation of insulin releasing cells, islets of Langerhans (islets), as a treatment for patients with insulin dependent diabetes. However, implantation of living cells into a host induces various undesirable biological responses similar to the responses against artificial materials, such as blood coagulation, complement activation, inflammatory reactions, and immune reactions. Understanding biological responses to artificial materials [2] and surface modification methods for biomaterials gives bases to evade adverse host responses and to improve functions of transplanted cells. For living cells and tissues, however, surface treatment should be carried out under the physiological condition not to deteriorate their viability and biological functions. We developed new methods to modify the surfaces of cells and tissues to increase their compatibility with a host environment. In the last part of this review, we discuss the latest methods for modifying islet surfaces and their effects on islet-host compatibility. 


\section{Cell adhesion to a model biomaterial surface}

\subsection{Self-assembled monolayer as a model surface}

Self-assembled monolayers (SAMs) of alkanethiols, $\mathrm{HS}\left(\mathrm{CH}_{2}\right)_{\mathrm{n}} \mathrm{X}$, where $\mathrm{X}$ denotes various functional groups, are frequently used to prepare model surfaces [3-6]. Alkanethiols or alkanedisulfides chemisorb from a solution onto a surface coated with metal, like gold, silver, or platinum. SAMs are commonly formed on a thin gold layer coated on a glass plate, due to its easy preparation and its stability in the ambient environment. Furthermore, gold is compatible with sensitive methods for analyzing surface phenomena, including surface plasmon resonance (SPR) [12], ellipsometry [13], Fourier transformed infrared - reflection adsorption spectroscopy (FTIR-RAS) [13], and quartz crystal microbalance (QCM) [14]. The gold sulfur bond is relatively stable, with a $\Delta \mathrm{H}^{\circ} \approx 28 \mathrm{kcal} / \mathrm{mol}[15,16]$. In addition, alkanethiols self-assemble through van der Waals interactions between alkyl chains. Alkanethiols with long alkyl chains $(\mathrm{n}>11)$ form closely-packed SAMs, with approximately $21.4 \AA^{2}$ of occupied area per molecule $[17,18]$. Due to the thiol anchoring to the gold and the close packing of the alkyl chain, another terminal group, X, can be effectively displayed on the surface of the SAM. Alkanethiols with various functional groups (X) are commercially available, and SAMs with different functional groups are easily prepared.

The surface properties of SAMs can be finely controlled by coadsorbing a mixture of alkanethiols with different functional groups. The composition of a SAM can be determined by spectroscopic methods like Fourier FTIR-RAS and X-ray photoelectron spectroscopy (XPS). The fraction of given alkanethiol on the mixed SAM surface reflects its mole fraction in the mixed solution, but it is not a linear relationship. The adsorbed fraction is highly dependent on the chain length of alkanethiol [19] and its terminal functional group [20,21]. The water contact angle measurement of mixed SAMs gradually changes with the fraction of mixed SAMs 
on the surface, and the relationship can be approximately expressed with Cassie's equation. Thus, the preparation of mixed SAMs with different alkanethiols allows us to systematically change the surface properties to produce a variety of different model surfaces.

A micropattern can be printed onto the SAM surface. This is achieved by UV light irradiation through a photo mask to cause photo degradation of alkanethiols [2224] or by microcontact printing with a pattern stamp made from poly(dimethylsiloxane) [25,26]. Micropatterned SAMs have been employed as a high throughput platform for studies on biomolecular interactions that included arrays of DNAs [27-29], proteins [30-33], and cells [34-37]. Micropatterned SAMs have also been used to examine cell fate after controlling the geometry of cell adhesion on a micrometer scale [38-41].

\subsection{Cell adhesion on material surfaces}

When a cell suspension is applied to a surface, the events that occur can be conceptually classified into three stages: (1) a cell approaches the surface, (2) the cell attaches to the surface, and (3) the cell adheres, and thus, spreads out on the surface. Most studies of cell adhesion on artificial materials measure the number of adherent cells, the cell morphology, and changes in protein expression. To gain more detailed insight into the biophysical mechanism of cell adhesion requires real-time tracking of cell behavior. To observe initial cell adhesion onto SAMs in real-time, we employed a total internal reflection fluorescence microscope (TIRFM).

The optical assembly of a TIRFM is schematically shown in Figure 1a [42]. The TIRFM utilizes an evanescent field, which is generated by laser reflection at a water/glass interface $[43,44]$. The intensity of the evanescent field decays exponentially with increasing distance from the interface. The characteristic penetration 
depth of the evanescent field is approximately $100 \mathrm{~nm}$ (depending on wavelength, incident angle, and refractive index of the glass and aqueous solution). Fluorescent dyes are excited in the evanescent field, and the emitted fluorescent light is captured with a CCD camera.

We assembled a TIRFM with low magnification to study cell adhesion behavior on SAMs with various functional groups [42]. Figure $1 \mathrm{~b}$ shows a schematic illustration of the cell adhesion process and the corresponding TIRFM images. A suspension of cells with fluorescently labeled cell membranes is applied onto a substrate (Figure 1 b-1). At first, no bright spots were observed by TIRFM, because the cells were in the medium, outside of the evanescent field. When the cells approached and landed on the surface (Figure $1 \mathrm{~b}-2$ ), small, bright spots were observed. The cells were round with diameters of approximately $10 \mu \mathrm{m}$, but the diameter of the cell membrane visualized in the evanescent field was approximately $2 \mu \mathrm{m}$. These spots were difficult to detect by TIRFM with a 10× objective lens. Once cells adhered to the SAM surface (Figure 1 b-3), bright spots were easily detected by TIRFM. When cells spread out on the surface (Figure $1 \mathrm{~b}-4$ ), the bright spots observed by TIRFM became larger with time. Thus, TIRFM was a useful tool for investigating cell adhesion. Changes observed in labeled cells could be interpreted to infer cell behavior at the solid/liquid interface.

TIRFM was used for time-lapse observations of initial cell adhesion to SAMs with different surface functionalities (Figure 2). After $10 \mathrm{~min}$ of plating a suspension of human umbilical vein endothelial cells (HUVECs), a few bright spots were observed on SAMs with $\mathrm{COOH}$ and $\mathrm{NH}_{2}$ functionalities; this indicated cell adherence. The number of bright spots increased and the spot areas enlarged with incubation time, indicating that HUVECs adhered and spread well on $\mathrm{COOH}-$ and $\mathrm{NH}_{2}$-SAM surfaces. Quantitative analysis of the number of adherent cells and cell adhesion areas on $\mathrm{COOH}$ - and $\mathrm{NH}_{2}$-SAMs showed that cell adhesion reached equilibrium after $60 \mathrm{~min}$ of incubation, but the adhesion area increased up to 180 min. In contrast, no spot was observed on $\mathrm{SAMs}$ with $\mathrm{CH}_{3}$ and $\mathrm{OH}$ functionalities. The number and total area of bright spots were much lower on $\mathrm{OH}-$ and $\mathrm{CH}_{3}-$ 
SAMs than on $\mathrm{COOH}-$ and $\mathrm{NH}_{2}$-SAMs at all times observed. After $60 \mathrm{~min}$, some bright spots were observed on OH-SAMs, but not on $\mathrm{CH}_{3}$-SAMs. This indicated that HUVECs adhered poorly to OH-SAM surfaces and worse to $\mathrm{CH}_{3}$-SAMs. The effects of surface functional groups on SAMs have been extensively studied with various cell lines. Those studies showed that most cell types adhered well to $\mathrm{COOH}-$ and $\mathrm{NH}_{2}$-SAMs and poorly to $\mathrm{CH}_{3}$ - and $\mathrm{OH}-\mathrm{SAMs}$ [45-50].

Other studies used various polymers to investigate how cell adhesion depended on the wettability of materials. They showed that cells adhered well to moderately wettable materials with water contact angles of $40-60^{\circ}$ [51-57]. However, the results were inconclusive. They employed polymeric materials composed of different chemicals that changed wettability concomitantly with changes in the SAM surface functionality. We performed a study with mixed SAMs to determine the effect of contact angles on cell adhesion [21]. SAMs with widely varying wettabilities were prepared by mixing two alkanethiols with different functional groups $\left(\mathrm{CH}_{3} / \mathrm{OH}, \mathrm{CH}_{3} / \mathrm{COOH}\right.$, and $\left.\mathrm{CH}_{3} / \mathrm{NH}_{2}\right)$. Figure 3 shows that the number of adherent cells depended on the contact angles of SAMs for both HUVECs and human cervical carcinoma (HeLa) cells. The maximum number of adherent cells occurred at different contact angles for all of these mixed SAMs, and it was different for different cell types. Thus, the design of a surface that promotes cell adhesion should take into consideration both the type of surface functional groups and the types of cells targeted.

\subsection{Effect of protein adsorption on cell adhesion}

When cells are suspended in a biological fluid or culture medium, both serum proteins and cells interact with the surface substrate. Serum protein adsorption behavior on SAMs has been examined with various analytical methods, including surface plasmon resonance (SPR) [58-61], ellipsometry [13,62,63], and quartz crystal 
microbalance (QCM) [64-66]. These methods allow in situ, highly sensitive detection of protein adsorption without any fluorescence or radioisotope labeling. SPR and QCM are compatible with SAMs that comprise alkanethiols. In our laboratory, we employed SPR to monitor protein adsorption on SAMs.

SPR detects changes in the refractive index near the surface of a metal film. Two optical configurations, Kretchmann (Figure 4a) and Otto, can be applied with SPR. The former is easily set-up and is suitable for protein adsorption on SAMs. A beam of $p$-polarized light is directed, through a prism, to the back side of a sample glass plate, which is coated with a metal thin film. The front side of the sample glass plate faces the solution of interest. When the incident angle, $\theta$ exceeds the critical angle, total internal reflection occurs. An evanescent wave is generated on the surface facing the solution, which has a lower refractive index than glass. At a specific incident angle, the evanescent wave of the incoming light is able to couple with the free oscillating electrons (plasmons) in the metal film, and surface plasmon resonance occurs. This resonance causes an energy transfer from the incident light to the plasmons of the metal film, which reduces the intensity of the reflected light (black line in Fig. 4b). Another important point in SPR is that the resonance angle is affected by the refractive index in the vicinity of the metal film (within $\sim 200 \mathrm{~nm}$ from the metal surface). Thus, a shift in resonance angle reflects events at the interface, like protein adsorption on the surface. The resonance angle shift $(\Delta \theta)$ after protein adsorption is related to the amount of adsorbed protein by the Fresnel relationship [67,68]. This equation assumes five layers (glass/Au/SAM/protein/water); the refractive index and the density of the protein layer are usually taken as 1.45 and $1 \mathrm{~g} / \mathrm{cm}^{3}$, respectively. For real-time analysis, the change in reflectance $(\Delta R)$ is tracked at a fixed incident angle (usually $0.5^{\circ}$ lower than the resonance angle) during a measurement, and then it is numerically converted to the resonance angle shift.

Figure $4 \mathrm{c}$ shows one example of the time course of an SPR angle shift during exposure of a $\mathrm{NH}_{2}$-SAM to culture medium supplemented with $2 \% \mathrm{FBS}$. It also includes the time course of the fraction of adherent cells on same surface determined 
by TIRFM observation (Fig. 2). The SPR angle shift rapidly increased, and then leveled off within a few minutes. Cells adhered much more slowly than proteins. Those results indicated that serum proteins in a medium rapidly adsorbed to the surface; then, cells interacted with the adsorbed protein layer, as shown schematically in Figure 5.

Thus, cell adhesion is determined by non-specifically adsorbed serum proteins on the surface. Therefore, it is important to consider the characteristics of adsorbed proteins including the amount, composition, and conformation / orientation.

\subsubsection{Amount of protein on a surface}

To suppress cell adhesion on a material surface, one approach is to inhibit the adsorption of proteins. SAMs of alkanethiols that carry oligo(ethylene glycol) (OEG) [69] and phosphorylcholine [70-72] have been shown to prevent nonspecific adsorption; thus, they effectively prevented cell adhesion. Several studies have described surfaces that prevent non-specific protein adsorption [73-75]; those surfaces are also likely to prevent cell adhesion.

We examined protein adsorption to SAMs that carried four different functional groups [42] and mixed SAMs with different wettabilities [21]. Large amounts of serum proteins adsorbed to all these SAMs, but the different surface functional groups greatly affected cell adhesion behavior (Figs. 2 and 3). Thus, the amount of adsorbed proteins did not correlate to the degree of cell adhesion to SAMs.

\subsubsection{Protein composition on a surface}

Serum glycoproteins, like fibronectin $(\mathrm{Fn})$ and vitronectin $(\mathrm{Vn})$, play a crucial role in cell adhesion to artificial materials. These proteins carry peptide motifs, including arginine-glycine-aspartic acid (RGD) [76] and proline-histidine-serine- 
arginine-asparagine (PHSRN) [77], that specifically interact with integrin receptors on cell membranes. Adsorption of Fn and Vn onto a material surface is required to support cell adhesion. However, the concentrations of Fn and Vn in serum are much lower than that of albumin and IgG (Fig. 4d). The composition of proteins initially adsorbed to a surface reflects the concentrations of each protein in the medium; thus, most proteins on the surface will be albumin and IgG., which cannot support cell adhesion. Controlling the composition of proteins in a solution is important for controlling cell adhesion on artificial materials.

Various methods have been used to examine the composition of proteins adsorbed to SAMs. Overall adsorption patterns can be examined with sodium dodecyl sulfate polyacrylamide gel electrophoresis (SDS-PAGE) [50,78,79]. Absorbed proteins are eluted from the surface with surfactant (SDS), and then separated by electrophoresis. The proteins of interest are examined by Western blotting $[50,78,79]$. Protein-specific antibodies can be used to detect proteins of interest $[19,62,78]$, or radiolabeled proteins can be added to the serum [45,80]. Lestelius et al used ellipsometry to examine antibody binding to 12 different plasma proteins that adhered to SAMs exposed to human plasma. Those SAMs carried terminal methyl $\left(-\mathrm{CH}_{3}\right)$, trifluoromethyl ester $\left(-\mathrm{OCOCF}_{3}\right)$, sulfate $\left(-\mathrm{OSO}_{3} \mathrm{H}\right)$, carboxyl ($\mathrm{COOH})$, or hydroxyl (-OH) groups [62]. Adherence of proteins relevant to coagulation and complement activation depended on the surface functionalities of SAMs. The sulfate and the carboxyl surfaces captured coagulation proteins, like high molecular weight kininogen, factor XII, and prekallikrein; the hydroxyl surface captured low amounts of complement protein, $\mathrm{C} 3 \mathrm{c}$. Tidwell et al reported the adsorption of radiolabeled fibronectin to SAMs with terminal methyl $\left(-\mathrm{CH}_{3}\right)$, hydroxyl $(-\mathrm{OH})$, carboxyl $(-\mathrm{COOH})$, and methyl ester $\left(-\mathrm{COOCH}_{3}\right)$ groups in $10 \%$ bovine serum [45]. COOH-SAM exhibited high levels of Fn adsorption, which correlated well with the adhesion of endothelial cells.

Figure $4 \mathrm{c}$ shows that the amount of adsorbed proteins is rapidly saturated within several minutes of exposing serum-containing medium to a surface. Albumin, the most abundant serum protein, was expected to preferentially adsorb onto the sur- 
faces during early time points. Then, adsorbed albumin was expected to be displaced by cell adhesion proteins. To investigate the effect of preadsorbed albumin displacement on cell adhesion, SAMs were first exposed to albumin; then, HUVECs suspended in a serum-supplemented medium were added [21,42]. Very few cells adhered to hydrophobic SAMs that had been pretreated with albumin, due to the large interfacial tension between water and the hydrophobic surfactantlike surface. Albumin was infrequently displaced by cell adhesive proteins, Fn and Vn. One the other hand, HUVECs adhered well to hydrophilic SAM surfaces that had been preadsorbed with albumin. In that case, the preadsorbed albumin was readily displaced with cell adhesive proteins.

\subsubsection{Protein conformation/orientation on a surface}

Proteins undergo conformational (or orientational) changes after adsorption to a material surface, which can influence their subsequent biological functions. Cells adhere to a surface through an interaction between integrin receptors on the cell membrane and the specific amino acid sequences, RGD and PHSRN, of cell adhesion proteins. When cell adhesion proteins undergo a conformational (or orientational) change that hinders the integrin binding site, cells cannot adhere to the surface.

The conformation/orientation of adsorbed proteins has been examined with monoclonal antibodies that recognize a specific site in a protein of interest. Keselowsky et al examined the conformation of Fn adsorbed to SAMs that carried methyl, hydroxyl, carboxyl, and amine groups [81]. They used monoclonal antibodies that recognized the central cell-binding domain of Fn near the RGD motif. Different SAM functionalities differentially modulated the binding affinities of the monoclonal antibodies $\left(\mathrm{OH}>\mathrm{COOH}=\mathrm{NH}_{2}>\mathrm{CH}_{3}\right)$. The strength of cell adhesion to these SAMs was correlated to the affinities of the Fn-specific monoclonal antibodies. Although antibody-based measurements could not distinguish between con- 
formational (structural) and orientational changes in the adsorbed proteins, they provided information about the biological activity of adsorbed proteins.

\subsubsection{Cell adhesion in serum free medium}

Cells are sometimes cultured in serum-free medium. In this condition, the surface should carry substituents of serum proteins that can directly interact with cells. SAMs of alkanethiols with bioactive ligands have been used to control interactions between the material surface and cells [82-85]. Several bioactive ligands have been tested, including RGD [82], PHSRN [83], and laminin-derived peptides $[84,85]$. These ligands were expected to directly interact with cell surface integrins.

SAMs of alkanethiols that carried RGD peptides were tested to determine the minimum amount of peptide required for cell adhesion to the substrate. Roberts et al employed SAMs of alkanethiols with mixtures of RGD and oligo(ethylene glycol) moieties that resisted non-specific protein and cell adsorption [82]. Bovine capillary endothelial cells attached and spread on SAMs that had a mole fraction of $\operatorname{RGD}\left(\chi_{\mathrm{RGD}}\right) \geq 10^{-5}$. Cell spreading reached a maximum at $\chi_{\mathrm{RGD}} \geq 10^{-3}$. This fraction indicated that the RGD density was on the order of $10^{11}$ RGD molecules $/ \mathrm{cm}^{2}$, assuming that the RGD occupied an alkanethiol area of $\sim 0.25 \mathrm{~nm}^{2} /$ molecule. Arnold et al designed a hexagonally-close-packed rigid template of cell-adhesive gold nanodots coated with cyclic RGDfK peptide. They used block-copolymer micelle nanolithography to create a patterned surface [86]. The gold nanodots were placed with $28,58,73$, or $85 \mathrm{~nm}$ spacing, based on the molecular weight of the block-copolymer. Adhesion tests with osteoblasts, fibroblasts, and melanocytes showed that cells adhered and spread on the patterned gold nanodots with a spacing of $\leq 58 \mathrm{~nm}$. This result also showed that the RGD density was on the order of $10^{11}$ molecules $/ \mathrm{cm}^{2}$. 


\section{Cell culture substrates for specific cell proliferation}

In standard cell culture methods, cells are plated in a cell culture flask or Petri dish, and they are maintained in medium supplemented with FBS and various growth factors. Cells adhere to the substrate through integrin and cell adhesion glycoproteins that adsorb to the plastic surface of the flask or dish. Primary cells isolated from embryonic and adult tissues are widely cultured with these methods. Nevertheless, it appears that this conventional culture method is inefficient for the production of specific cells in high purity and large quantities. Although different kinds of cells isolated from widely different tissues can adhere and proliferate in cell culture flasks, efficiency may be limited by the heterogeneity of cell populations.

To overcome these limitations, we have developed culture substrates that enable the highly efficient expansion of specific cells in adherent cultures [37,87-90]. An important characteristic of these substrates is that specifically-engineered growth factors are immobilized on the surface. Extensive protein engineering techniques were used to optimize the presentation of growth factors to cells.

\subsection{Strategy for adherent cultures of neural stem cells}

Neural stem cells (NSCs), capable of self-renewal and differentiation into multiple cell types, are found in embryonic and adult tissues of the central nervous system (CNS) [91]. Several studies have demonstrated that NSCs are a potential source for cell replacement therapies in CNS disorders [92,93]. Those studies have largely relied on the ability to culture NSCs in vitro. To develop culture substrates for the selective expansion of NSCs, we first considered the responsiveness of NSCs to growth factors. Originally, NSCs were discovered as EGF-responsive cells from rodent CNS tissue [11]. Another study [36] showed that the expression of the EGR 
receptor (EGFR) on rat neurosphere-forming cells was highly correlated to the expression of nestin, an intracellular marker for NSCs. In addition, EGF was shown to be a mitogen for NSCs. Based on these results, we hypothesized that a substrate with surface-immobilized EGF might selectively trap NSCs from a heterogeneous population of cells. Furthermore, the EGF-EGFR interactions that would specifically capture NSCs might also promote NSC proliferation due to EGFR signaling. To test this hypothesis, we focused on surface immobilization of EGF for the selective expansion of rat NSCs.

\subsection{Oriented immobilization of engineered epidermal growth factor}

There are many protein immobilization techniques available. One of the standard techniques uses amine chemistry, where surface-bound nucleophilic groups react with amines, which are abundant in proteins [94]. Although this technique provides covalent immobilization of proteins, the use of amines would cause protein inactivation. In addition, it does not provide control over the orientation of the immobilized protein to ensure efficient recognition by ligands. On the other hand, recombinant DNA technology can overcome these problems. A recombinant protein can be designed that has a specific peptide motif at a given site in the molecule for surface anchoring.

We used recombinant DNA technology to design unique substrates for in vitro expansion of rat NSCs. For example, we fused a small peptide sequence of six consecutive histidines (His) to the C-terminus of human EGF (EGF-His). This EGFHis was anchored to the surface of a glass-based substrate by coordination with $\mathrm{Ni}^{2+}$ ion, which was fixed on the surface of a SAM of alkanethiol. Strikingly, neither a covalently immobilized EGF-His nor a physically adsorbed EGF-His could trap cells as efficiently as EGF-His immobilized by surface anchoring through coordination. 
To prepare a $\mathrm{Ni}^{2+}$-chelated surface, a thin gold layer was deposited onto a glass plate; then, on the gold surface, a SAM was formed that terminated with trivalent carboxylic acids; finally, $\mathrm{Ni}^{2+}$ ions were chelated to the acidic termini. In detail, first, thin chromium and gold layers were deposited onto the surface of a glass plate with a vacuum evaporator. The glass plate was then immersed in ethanol that contained 16-mercapto-1-hexadecanoic acid (COOH-thiol) and (1mercaptoundec-11-yl)triethylene glycol (TEG-thiol) at various compositions to allow the formation of mixed SAMs. Each glass plate coated with a mixed SAM was immersed in a solution containing $N, N$ '-dicyclohexylcarbodiimide and $N$ hydroxysuccinimide, which converted the terminal carboxylic acid to an active ester. Subsequently, a solution of $N$-(5-amino-1-carboxypentyl) iminodiacetic acid (NTA) was plated onto the activated surface to introduce triacetic acid. The glass plate was then immersed in a $\mathrm{NiSO}_{4}$ solution to form the $\mathrm{Ni}^{2+}$ chelate. Finally, an EGF-His solution was plated onto the $\mathrm{Ni}^{2+}$-chelated surface to allow immobilization of EGF-His through the coordination of $\mathrm{Ni}^{2+}$ with His. A His-tagged protein firmly binds to a $\mathrm{Ni}^{2+}$-chelated substrate; for instance, histidine-tagged green fluorescent protein bound to NTA- $\mathrm{Ni}^{2+}$ with a dissociation constant of $4.2 \times 10^{-7} \mathrm{M}$ [95]. The mixed SAM surface was characterized by water contact angle measurements, infrared reflection adsorption spectroscopy, and X-ray photoelectron spectroscopy. These revealed the formation of well-defined surfaces. The expected structure of an EGF-His-immobilized surface is schematically depicted in Figure 6. The surface density of immobilized EGF-His increased with increases in the $\mathrm{COOH}$-thiol content of the $\mathrm{COOH}$-thiol/TEG-thiol mixture used to prepare the SAM. The maximum EGF-His density was approximately $0.4 \mu \mathrm{g} / \mathrm{cm}^{2}$ with $100 \%$ COOH-thiol.

The incorporation of TEG-thiol onto a $\mathrm{COOH}$-thiol SAM elevated the fraction of correctly-oriented EGF-His on the surface by preventing non-specific adsorption of EGF onto the SAM surface. This might be explained by the following findings. The area occupied by a single EGF molecule $\left(2.98 \mathrm{~nm}^{2} /\right.$ molecule) [96] is approximately 10 times larger than the area occupied by $\mathrm{COOH}$-thiol $(0.25$ 
$\mathrm{nm}^{2} /$ molecule $)$ [97] or TEG-thiol $\left(0.35 \mathrm{~nm}^{2} /\right.$ molecule $)$ [98]. Therefore, on a surface of $100 \% \mathrm{COOH}$-thiol, the majority of $\mathrm{COOH}$-thiol molecules would not be expected to be involved in the coordination with EGF-His. Instead, the excess carboxylic acids contained in $\mathrm{COOH}$-thiol and NTA would be expected to trigger non-specific adsorption of EGF-His. Under conditions where the COOH-thiol content was $10-15 \%$, and $80 \%$ of $\mathrm{COOH}$-thiol was converted to $\mathrm{Ni}^{2+}$ chelate, the predicted density of $\mathrm{Ni}^{2+}$ chelate would be equivalent to that of closely-packed EGF-His in a monolayer. However, higher surface densities of $\mathrm{COOH}$-thiol gave rise to larger amounts of immobilized EGF-His without obvious saturation at 10 $15 \% \mathrm{COOH}$-thiol. This was probably due to the non-specific EGF-His binding to residual carboxylic acids present on the surface after NTA derivatization and $\mathrm{Ni}^{2+}$ chelation. Furthermore, these non-specifically bound EGF-His molecules may hinder access to the $\mathrm{Ni}^{2+}$ sites for specific coordination.

\subsection{Proliferation of rat NSCs on EGF-His-immobilized surface}

We investigated the efficiency of NSC expansion on surfaces with EGF-His immobilized in the correct orientation. NSCs were obtained from neurosphere cultures prepared from fetal rat striatum harvested on embryonic day 16. NSCs were cultured for 5 days on EGF-His-immobilized substrates prepared with mixed SAMs of different $\mathrm{COOH}$-thiol contents. Cells adhered and formed network structures at a density that increased with the $\mathrm{COOH}$-content of the surface. As a control, cells were seeded onto surfaces without immobilized EGF-His. This resulted in poor cell adhesion during the entire culture period. In addition, when EGF-His adsorbed to SAMs with $100 \% \mathrm{COOH}$-thiol or SAMs with NTA-derivatized $\mathrm{COOH}$ that lacked $\mathrm{Ni}^{2+}$ chelation, we observed poor initial cell adhesion, and the cells formed aggregates within 5 days. Interestingly, the substrate used to covalently immobilize EGF-His with the standard carbodiimide chemistry was not a 
suitable surface for cell adhesion and proliferation. The control experimental results contrasted markedly with results from EGF-His-chelated surfaces.

As described earlier, the surface density of immobilized EGF-His was shown to be directly correlated to the $\mathrm{COOH}$-thiol content. Therefore, we reasoned that the initial cell attachment must involve an interaction between immobilized EGF-His and an EGFR expressed on the cell membrane. In fact, reverse transcriptasepolymerase chain reaction assays revealed that neurosphere cells expressed EGFR mRNA. In addition, cell adhesion to immobilized EGF-His was totally inhibited when soluble EGF was added to the culture medium at $20 \mathrm{ng} / \mathrm{mL}$. Flow cytometry analyses further demonstrated that rat neurosphere cultures could be significantly enriched in NSCs by plating cells onto a glass surface with immobilized EGF-His. All these findings supported our hypothesis that cell adhesion was mediated by an EGF-EGFR interaction.

Table 1 summarizes the results of proliferation assays carried out on EGF-Hisimmobilized surfaces. The total cell number after 5 days of culture varied with different surfaces. These differences could be attributed principally to differences in the numbers of cells initially attached, demonstrated by the cell numbers observed at $24 \mathrm{~h}$. The doubling time, determined for the $24-72 \mathrm{~h}$ period after cell seeding, was similar for all the surfaces, with an average of $16.9 \pm 4.7 \mathrm{~h}$. The mitogenic signal of EGF might have been saturated on all surfaces, including the surface with the lowest EGF density. The doubling time determined on the EGF-Hisimmobilized surfaces was approximately half the doubling time determined for the neurosphere culture $(31.2 \pm 1.4 \mathrm{~h})$. On the surfaces with $0.01,0.1$, and $1 \% \mathrm{COOH}$ thiol content, the growth rate declined slightly after $96 \mathrm{~h}$; this was probably due to a reduction of EGF activity after 4-5 days.

NSC content was assessed in a population of cells expanded on EGF-Hisimmobilized surfaces for 5 days. Cells were immunocytochemically stained with antibodies specific for nestin, a marker for NSCs, and $\beta$-tubulin III ( $\beta$ III), a marker for differentiated neurons. The number of cells that expressed nestin and $\beta$ III was expressed as the percent of the total number of cells in the culture flask (Figure 7). 
Cells with a nestin ${ }^{+} \beta \mathrm{III}^{-}$phenotype represented the most immature population. Both nestin ${ }^{+} \beta \mathrm{III}^{-}$cells and the total number of nestin ${ }^{+}$cells (nestin ${ }^{+} \beta \mathrm{III}^{-}$plus nestin $\left.^{+} \beta \mathrm{III}^{+}\right)$were most abundant on the surface with $10 \% \mathrm{COOH}$-thiol $(97 \pm$ $2.7 \%$ and $98 \pm 0.8 \%$, respectively). Although the abundance of cells with these phenotypes decreased with decreasing $\mathrm{COOH}$-thiol content, approximately $85 \%$ of all cells exhibited the nestin ${ }^{+} \beta \mathrm{III}^{-}$phenotype on the EGF-His-immobilized surface with $0.01 \% \mathrm{COOH}$-thiol.

We also conducted experiments to compare our culture method to the standard neurosphere culture. In the standard neurosphere culture, cell number increased approximately 9 times over 5 days. Immunostaining showed that the neurosphere cultures contained $54 \pm 5.3 \%$ nestin $^{+}$cells and $41 \pm 7.4 \%$ nestin $^{+} \beta \mathrm{III}^{-}$cells. This demonstrated that the standard neurosphere culturing method was less efficient than EGF-immobilized substrates for selectively expanding NSCs. Thus, the EGFimmobilized substrates prepared from mixed SAMs with $10 \% \mathrm{COOH}$-thiol provided the most efficient method for selective NSC expansion.

Cells that were expanded on EGF-immobilized substrates were harvested and cultured on freshly prepared EGF-His-immobilized substrate for another 5 days. These procedures were repeated up to 4 times. The rate of cell growth was not affected by repeated subculturing; the average doubling time was $18.1 \pm 1.8 \mathrm{~h}$. In addition, immunocytochemical staining showed that, after 4 subcultures, cells retained $93 \pm 2.0 \%$ nestin $^{+}$populations. These results suggested that, in theory, NSCs can be expanded by approximately $10^{5}-10^{6}$ fold within 20 days on the EGFHis-immobilized substrates. Furthermore, these cells retained multipotency. Under appropriate conditions, the cells differentiated to express $\beta$ III, GFAP (astrocyte marker), and $\mathrm{O} 4$ (oligodendrocyte marker) with marked reductions in nestin expression. The results of the differentiation assays suggested that expanded cells that expressed nestin retained, for the most part, multipotency and could differentiate into neuronal and glial lineages.

Based on those results, we concluded that, when cultured on the EGF-Hisimmobilized surface prepared from a mixed SAM of $10 \% \mathrm{COOH}$-thiol, highly- 
enriched NSC populations could be produced in large quantities. Over a 5-day culture on the substrate, cells were expanded 32 times. These expanded cells consisted of $98 \%$ nestin $^{+}$cells that retained multipotency for differentiating into neuronal and glial lineages. This suggested that selective expansion could be repeated for large-scale production of highly enriched NSC cells.

\subsection{Structural integrity and stability of immobilized EGF-His}

We wondered why NSCs proliferated exclusively on surfaces with EGF-His ligands anchored by coordination. We focused on two aspects in particular: the conformational integrity of coordinated EGF-His and the stability of coordinate bonds at the interface. Conformational information was acquired with multiple internal reflection-infrared absorption spectroscopy (MIR-IRAS) [99]. The stability of coordinate bonds was assessed by culturing NSCs on a surface with a small region of EGF-His ligands anchored by coordination. This spatially-restricted EGF-His anchoring enabled an intuitive exploration of EGF-His release under cell culture conditions.

The results of these studies showed that EGF-His coordinated to the $\mathrm{Ni}^{2+}$-chelated NTA-surface retained an intact conformation and was firmly anchored to the surface during NSC culturing procedures. Both attributes are essential for establishing adherent cultures and hence, selective expansion of NSCs. In contrast, with covalent immobilization, the structural integrity of EGF-His was reduced due to multivalent linkages to the surface. In physical adsorption, EGF-His maintained its intact conformation, but was readily released from the surface during cell culturing procedures. We concluded that structural integrity and firm anchorage were optimized with the coordination method. 


\subsection{Spontaneously dimerizing $E G F$}

Numerous studies have shown that EGF binding to EGFR triggers receptor dimerization. This is considered a critical step in intracellular signal transduction [100]. Inspired by this mechanism, we designed EGF chimeric proteins that spontaneously dimerized (dEGF-His). These dimers were terminally-anchored to the substrate. We expected that these pre-formed dimeric EGF structures would facilitate the formation of EGF-EGFR dimer complexes more efficiently than monomeric EGF structures.

Our strategy for the spontaneous dimerization of EGF was to incorporate an $\alpha$ helical oligopeptide with the ability to participate in forming a coiled-coil structure [101]. We implemented a heterodimerization system in which (KELASVK) (K5) and (EKLASVE) $)_{5}$ (E5) peptides could form stable coiled-coil heterodimers. We then synthesized two chimeric proteins that contained EGF attached to either the K5 (EGF-K5-His) or the E5 (EGF-E5-His). Both had the hexahistidine sequence added to the $\mathrm{C}$-terminus for anchoring through coordination with $\mathrm{Ni}^{2+}$ ions fixed to a substrate.

Analyses by native polyacrylamide gel electrophoresis and circular dichroism (CD) spectroscopy revealed that spontaneous coiled-coil associations between EGF-E5-His and EGF-K5-His promoted heterodimer (dEGF-His) formation. The CD spectroscopic analysis suggested that the E5 peptide in monomeric EGF-E5His had a disordered structure. However, the $\alpha$-helical structure was induced in the E5 peptide when it associated with EGF-K5-His. These findings are shown schematically in Figure 6.

We tested adhesion and proliferation of rat NSCs on surfaces with immobilized dEGF-His, EGF-K5-His, EGF-E5-His, or EGF-His. The surface with immobilized dEGF-His provided the highest efficiency for selective expansion of NSCs. On this substrate, cells expanded 60 -fold over $96 \mathrm{~h}$ of culture. Of note, over $98 \%$ of the expanded cells expressed nestin, but not $\beta$ III. 
The monomeric EGF-His appeared to be limited in its capacity for promoting EGFR dimerization, most likely due to the reduced mobility of surface-anchored EGF. In contrast, when dEGF-His was anchored to the surface, EGFR dimerization was most likely enhanced, because the EGF domains were paired in close proximity. Presumably, this would promote efficient proliferation of NSCs, as observed on the surface with immobilized dEGF-His. We estimated that the distance between two EGF domains in the dEGF-His dimer was approximately comparable to the distance between the two binding sites in dimerized EGFR [102]. We further observed that both EGF-E5-His and EGF-K5-His, anchored as single components, provided more efficient substrates than EGF-His alone. This might be explained by the E5 and K5 peptides inserted between the EGF domain and the His sequence; this extra component may have increased the mobility of the EGF domain, which may have enhanced its accessibility. Consistent with that notion, the effects of these peptides on cell proliferation were not detectable when the chimeric proteins were used as unattached, diffusible factors.

\subsection{Modules for culturing NSCs in a closed system}

The method for immobilizing EGF-His on SAMs gave rise to the need for fabricated cultureware that could allow large-scale expansion of pure NSCs. We attempted to construct culture modules with surface areas much larger than the laboratory-scale substrates described above. For uniformly anchoring EGF-His over a large area, we utilized a glass plate with amine functionalities on the surface. We also found that a gold layer was not required or advantageous for general use of the technique.

First, the surface of a glass plate $(60 \mathrm{~mm} \times 60 \mathrm{~mm} \times 1 \mathrm{~mm})$ was modified with 3aminopropyltriethoxysilane (APTES) to introduce the amine functionality. The surface amine was reacted with glutaraldehyde to introduce aldehyde, and then it 
was exposed to a solution of NTA; NTA coupling occurred through the formation of a Schiff base. Subsequently, the glass plate was immersed in a $\mathrm{NiSO}_{4}$ solution to chelate $\mathrm{Ni}^{2+}$ ions. Finally, EGF-His was anchored to the $\mathrm{Ni}^{2+}$-chelated surface to obtain an EGF-His-immobilized glass plate. The surface density of coordinated EGF-His was $0.53 \pm 0.10 \mu \mathrm{g} / \mathrm{cm}^{2}$, measured with the microBCA assay. The MIRIRAS spectrum of this surface exhibited strong absorption at amide I' and amide II' bands (the prime notation designates a deuterated condition), which indicated the presence of EGF-His at the surface. The conformations of characteristic secondary structures was determined from the amide I' band. The results showed that the content of $\beta$-sheet and $\beta$-turn structures in surface-anchored EGF-His was similar to those observed in native EGF in solution and in EGF-His anchored to a $\mathrm{Ni}^{2+}$-bound surface created on an alkanethiol SAM.

To fabricate a culture module, we adhered a silicon frame to the edges of the plate to enclose the sides; then, a polystyrene film was adhered to the top of the frame to allow gas exchange. This culture module provided an area of $25 \mathrm{~cm}^{2}$ and a chamber volume of $2.5 \mathrm{~mL}$. To test the modules, we injected dissociated rat neurosphere-forming cells. After 4 days of culture, $5 \times 10^{6}$ cells were obtained per module. These cells could be subcultured in new modules. We performed 6 passages by sub-culturing every 4 days. At each sub-culture, a part of the recovered cells were seeded to a freshly prepared module at a density of $3.0 \times 10^{4}$ cells $/ \mathrm{cm}^{2}$. The average number of cells harvested after each subculture was $5.4 \pm 1.7 \times 10^{6}$ cells per module. We determined that $95 \%$ of the total number of cells had a phenotype of nestin ${ }^{+} \beta \mathrm{III}^{-}$. In addition, the cells obtained after 6 passages could be differentiated, under appropriate conditions, into three major lineages, including neurons, astrocytes, and oligodendrocytes. This demonstrated that the cells maintained multipotency.

The culture module greatly facilitated homogeneous distribution of seeded cells and cultivation of a large number of cells under identical conditions. In addition, the module required a smaller volume of medium than standard cell culture systems. Importantly, this modular system provided the great advantages of scalabil- 
ity and safety because cell processing can be performed in a closed system. Thus, the modules facilitate the production of cells that are safe for use in cell transplantation therapies.

In a separate study [90], we synthesized EGF fused to a polystyrene-binding peptide [103] (EGF-PSt) that could be immobilized on the surface of a tissue culture polystyrene dish. This surface also permitted efficient expansion of NSCs. Thus, EGF-PSt can be used to produce large quantities of pure NSCs in standard laboratories.

\section{Cell surface modifications}

Cell surfaces can be modified in a number of ways, including covalent conjugation of polymers to amino groups on membrane proteins [104-107], electrostatic interaction between cationic polymers and a negatively charged cell surface [108111], and hydrophobic interactions that anchor long alkyl chains of amphiphilic polymers to the lipid bilayer of the cell membrane [112-128]. These methods have been used to immobilize various functional groups and bioactive substances onto the cell surface. The covalent conjugation method is expected to impair membrane protein functions because polymers are attached by crosslinking to the amino groups on membrane proteins. Therefore, the extent of this reaction should be carefully controlled. The electrostatic interaction is performed by simply adding a cationic polymer solution to a cell suspension. However, most cationic polymers are cytotoxic; therefore, this treatment causes deterioration or death to most cell types. In contrast, the hydrophobic interaction can be performed by simply adding amphiphilic polymers with long alkyl chains to a cell suspension. This has not caused any major damage to cell function or integrity. Our group has extensively studied surface modifications with amphiphilic polymers [112-128]. 


\subsection{Cell surface modifications with amphiphilic polymers}

Amphiphilic polymers are typically derived by conjugating polyethylene glycol (PEG) to a phospholipid (PEG-lipid) (Fig. 8) [119, 120]. When a PEG-lipid solution is added to a cell suspension, the hydrophobic alkyl chains of the PEG-lipid spontaneously form hydrophobic interactions with the lipid bilayer of the cell membrane (Fig. 8a). This spontaneous anchoring of the PEG-lipid to a supported lipid membrane was confirmed by observation with surface plasmon resonance (SPR) (Fig. 9a). Three kinds of PEG-lipids with different alkyl chain lengths were added to a lipid membrane that had been created on a SPR sensor surface. The SPR angle rapidly increased with the spontaneous anchoring of PEG-lipid into the lipid membrane. In addition, the anchoring rates decreased with increasing alkyl chain lengths. This spontaneous anchoring was also demonstrated with a human cell line derived from $\mathrm{T}$ cell leukemia cells (CCRF-CEM). A solution of fluorescein isothiocyanate (FITC)-conjugated PEG-lipid was added to a suspension of CCRF-CEM. Under a confocal laser scanning microscope, the bright fluorescence from FITC was observed at the periphery of all cells (Fig. 9b). This indicated that PEG-lipids had lodged on the cell surface. The retention time of PEG-lipids on cell membranes can be controlled by adjusting the length of the lipid alkyl chain. The dissociation rate of PEG-lipid was much slower with long than with short hydrophobic domains [113].

Proteins can be immobilized on the cell surface with the use of a short, single stranded DNA (ssDNA) attached to the end of a PEG chain (ssDNA-PEG-lipid) [116-118, 121, 127]. First, an ssDNA-PEG-lipid is prepared by conjugating maleimide-PEG-lipid with an ssDNA that carries a thiol group. Then, a protein is modified with a hetero-bifunctional cross-linker, sulfo-EMCS ( $N$-(6maleimidocaproyloxy)sulfosuccinimide); next, it is treated with a ssDNA' that is complementary to the ssDNA on the PEG-lipid. Figure 8 shows a schematic of the procedure, where the ssDNA and ssDNA' are oligo(deoxythymidine) (oligo $(\mathrm{dT})_{20}$ ) and oligo(deoxyadenine) (oligo $(\mathrm{dA})_{20}$ ), respectively. The cells with 
oligo $(\mathrm{dT})_{20}$ attached are exposed to the protein with the oligo $(\mathrm{dA})_{20}$ attached. The protein is immobilized on the cell through hybridization between oligo $(\mathrm{dT})_{20}$ and oligo $(\mathrm{dA})_{20}$.

Figure $9 \mathrm{c}$ shows the SPR profiles recorded before and after an oligo $(\mathrm{dT})_{20}$-PEGlipid had incorporated into the supported lipid membrane, and its interactions with oligo(dA $)_{20^{-}}$urokinase and oligo(dT) ${ }_{20}$-urokinase on the SPR sensor surface. The first increase in the SPR angle indicated that the oligo(dT) $)_{20}$-PEG-lipid had incorporated into the membrane; the second increase showed the binding of oligo(dA) $)_{20}$-urokinase to the oligo(dT) $)_{20}$ substrate (solid line). No increase was observed when oligo $(\mathrm{dT})_{20}$-urokinase was applied to the oligo $(\mathrm{dT})_{20}$ substrate (dashed line). These results indicated that protein could be specifically conjugated to the cell surface by hybridization between oligo $(\mathrm{dA})_{20}$ and oligo $(\mathrm{dT})_{20}$ moieties.

\subsection{Immobilization of bioactive substances on an islet surface}

Cell transplantation has shown promise as a method for treating serious diseases. Various kinds of pluripotent stem cells have been developed or identified, including embryonic stem (ES) cells, induced pluripotent stem (iPS) cells, and mesenchymal stem cells. Moreover, the differentiation of stem cells to functional cells has been extensively studied. Previous studies have demonstrated that the transplantation of islet of Langerhans cells (islets) could successfully treat type 1 diabetes. Islets are insulin secreting cells found in the pancreas. Over two hundred patients with type 1 diabetes have been clinically treated with islet transplantation. To cure the disease, a single patient typically requires islets from several donors, due to the destruction of islets just after transplantation. In the clinical setting, islets are infused into the liver through the portal vein. Exposure of islets to the blood activates blood coagulation and complement systems, which induce nonspecific inflammatory reactions or instant blood-mediated inflammatory reactions 
(IBMIR). These host defense mechanisms destroy donor islets because they are considered foreign bodies [129-131]. Anticoagulants, including aspirin, heparin, and dextran sulfate, are typically administered to inhibit blood coagulation. However, systemic infusion of these drugs increases bleeding. The optimal approach would be to prevent blood coagulation at the islet. Recent studies have been able to immobilize various bioactive substances, like heparin, urokinase, thrombomodulin, and the soluble domain of human complement receptor 1 (sCR1), on islets in attempts to control local activation of the blood coagulation and complement systems [112, 114, 117, 119-121, 123, 127].

As an example, we will describe immobilization of the fibrinolytic enzyme, urokinase (UK), on the islet surface $[117,121]$. As shown in Fig. 8, UK could be immobilized on islets through ssDNA hybridization of oligo(dT) $)_{20}$-PEG-lipid and oligo(dA $)_{20}$-UK. When the oligo(dT) $)_{20}$-PEG-lipid was added to a suspension of islets, the lipid moiety spontaneously anchored to the lipid bilayer of the cell membrane through hydrophobic interactions. The oligo $(\mathrm{dT})_{20}$ segment was exposed on the cell surface, which made it accessible for conjugation with the oligo $(\mathrm{dA})_{20}$ on UK (Fig. 8-c).

Fig. 10 shows confocal laser-scanning fluorescence images of islets treated with oligo(dT) ${ }_{20}$-PEG-lipid and oligo(dA) ${ }_{20}$-UK (UK-islets). In these experiments, lipids with different alkyl chain lengths were attached to the PEG moiety to test the stability of UK on the islet surface. Both PEG varieties showed clear fluorescence signals (Fig. 10a, b) from UK-islets, which indicated that both facilitated stable UK attachments. On the other hand, fluorescence was nearly undetectable on unmodified islets and islets treated with oligo $(\mathrm{dA})_{20}-\mathrm{UK}$ in the absence of oligo(dT) $)_{20}-$ PEG-lipids (Fig. 10-c). These results indicated that UK could be immobilized on islets through DNA hybridization. The retention time of the oligo(dT $)_{20}$-PEG-lipid on the cell membrane depended on the chain lengths of the PEG-lipid [113]. At 2 days after conjugation, a strong fluorescence signal was observed for islets treated with oligo(dT) ${ }_{20}$-PEG-lipid (C18), and a weaker fluorescence signal was observed for islets treated with oligo(dT) $)_{20}$-PEG-lipid $(\mathrm{C} 16)$. 
The longer alkyl chain length conferred longer retention of UK on the islet surface.

UK is a serine protease that activates plasminogen to plasmin. Plasmin dissolves the fibrin in blood clots. The attachment of UK to the islet surface was expected to dissolve blood clots that surrounded the islets in the liver; thus, IBMIR could be inhibited in the initial stages. A fibrin plate-based assay was performed to assess the function of the UK attached to the islets. Fifty islets with/without immobilization of UK were spotted onto a fibrin gel plate. After incubation, transparent areas around the spots indicated UK dissolution of the fibrin. Figure 11 shows the fibrin plate at $14 \mathrm{~h}$ after spotting the islets. Larger transparent areas were observed around the UK-islets compared to those around the unmodified islets (Figure 11a1, a-2, and a-4). These indicated that the immobilized UK retained its activity on the islets. UK-islets were also tested after 2 days of culture in the presence of serum (Figure 11a-3 and a-5). UK activity rapidly decreased with 2 days in culture. The morphology of all islets after modification with UK was well maintained after 7 days of culture (Fig. 11b). Islets with UK maintained the ability to regulate insulin release in response to changes in glucose concentration (data not shown). We also performed transplantation of UK-islets by transfusion to the liver through the portal vein [121]. The transplantation results indicated that donor islets were rescued from host defenses by attaching UK to their surfaces. It remains to be determined how long UK-islets can maintain the inhibition of IBMIR; however, these data suggested that UK immobilization on islets is a promising approach for islet transplantation.

\subsection{Encapsulation of islets with living cells}

The histocompatibility and blood compatibility of donor islets can be significantly improved by enclosing them inside a capsule made of the patient's vascular endo- 
thelial cells. The ssDNA-PEG-lipid method was utilized to enclose islets with living cells [127]. The method is schematically shown in Figure 12a. Oligo(dT) ${ }_{20}$ was introduced onto the surface of HEK293 cells with an oligo(dT) $)_{20}$-PEG-lipid, and oligo $(\mathrm{dA})_{20}$ was introduced onto the surface of islets with an oligo $(\mathrm{dA})_{20^{-}}$ PEG-lipid. Then, the oligo(dA $)_{20}$-islets were mixed with the oligo(dT) $)_{20}$-HEK293 cells. The HEK293 cells were immobilized on the islet surface through DNA hybridization, as shown in Fig. 12b. Although the HEK293 cells existed as single cells on the islet just after immobilization, the surface of islets were completely covered with a cell layer after 3 days in culture (Fig. 12b). No central necrosis of the islet cells was observed. Immunostaining showed that insulin remained inside the islets after culturing for 3 days (Fig. 12b). Furthermore, after cell encapsulation, insulin secretion in response to glucose stimulation was well maintained (data not shown). This technique will greatly facilitate islet transplantation for treating type 1 diabetes.

\section{Summary}

Understanding biological responses against foreign substances has led to the development of various medical devices, artificial organs, and regenerative medicine approaches. Self-assembled monolayers (SAMs) of alkanethiols formed on a thin gold layer coated on a glass plate provided a platform for studying protein adsorption and cell adhesion to artificial materials. Although many questions remain to be answered before we fully understand the mechanisms of cell adhesion to artificial materials, rational studies can be conducted with SAMs. SAMs were used for developing a culture substrate for selective proliferation of NSCs. Based on this finding, we constructed a NSC culture module to facilitate the large-scale production of highly pure NSCs. 
The ssDNA-PEG-lipid provides versatility in cell surface modifications. It enables the immobilization of a broad spectrum of proteins and low molecular weight drugs on living cell surfaces. The encapsulation of islets inside a cell layer illustrates the versatility of this approach. The concept of controlling the host defense response against a living cell graft is likely to lead to important steps forward in cellular therapies. Various types of functional cells can be derived from pluripotent stem cells, including ES cells, iPS cells, and mesenchymal stem cells for use in cell replacement therapies. Our method is likely to be a key technology for the control of both acute and chronic host reactions and facilitation of graft adaptation in patients. 


\section{References}

1. Park JB (1984) Tissue response to implants (biocompatibility). In: Park JB Biomaterials science and engineering. Plenum Press, New York.

2. Anderson JM, Cook G, Costerton B, Hanson SR, Hensten-Pettersen A, Jacobsen N et al (2004) Host reactions to biomaterials and their evaluation. In: Ratner BD, Hoffman AS, Schoen EJ, Lemons JE (ed) Biomaterials science: an introduction to materials in medicine, 2nd edn. Elsevier Academic Press, Amsterdam.

3. Ulman A (1996) Formation and structure of self-assembled monolayers. Chem Rev 96:15331554.

4. Ostuni E, Yan L, Whitesides GM (1999) The interaction of proteins and cells with selfassembled monolayers of alkanethiolates on gold and silver. Colloids Surf B 15:3-30.

5. Love JC, Estroff LA, Kriebel JK, Nuzzo RG, Whitesides GM (2005) Self-assembled monolayers of thiolates on metals as a form of nanotechnology. Chem Rev 105:1103-1169.

6. Senaratne W, Andruzzi L, Ober CK (2005) Self-assembled monolayers and polymer brushes in biotechnology: Current applications and future perspectives. Biomacromolecules 6:24272448.

7. Xu C, Inokuma MS, Denham J, Golds K, Kundu P, Gold JD, Carpenter MK (2001) Feederfree growth of undifferentiated human embryonic stem cells. Nature Biotechnol 19:971-974.

8. Flaim CJ, Chien S, Bhatia SN (2005) An extracellular matrix microarray for probing cellular differentiation. Nature Methods 2:119-125.

9. Soen Y, Mori A, Palmer TD, Brown PO (2006) Exploring the regulation of human neural precursor cell differentiation using arrays of signaling microenvironments. Mol Sys Biol doi:10.1038/msb4100076

10. Nakajima M, Ishimuro T, Kato K, Ko IK, Hirata I, Arima Y, Iwata H. (2007) Combinatorial protein display for the cell-based screening of biomaterials that direct neural stem cell differentiation. Biomaterials 28:1048-1060.

11. Reynolds BA, Tetzlaff W, Weiss SA (1992) A multipotent EGF-responsive striatal embryonic progenitor cell produces neurons and astrocytes. J Neurosci 12: 4565-4574 
12. Green RJ, Frazier RA, Shakesheff KM, Davies MC, Roberts CJ, Tendler SJB (2000) Surface plasmon resonance analysis of dynamic biological interactions with biomaterials. Biomaterials 21:1823-1835.

13. Tengvall P, Lundström I, Liedberg B (1998) Protein adsorption studies on model organic surfaces: an ellipsometric and infrared spectroscopic approach. Biomaterials 19:407-422.

14. Reimhult E, Larsson C, Kasemo B, Höök F (2004) Simultaneous SPR and QCM-D monitoring measurements of biomolecular adsorption events involving structural transformations and variations in coupled water. Anal Chem 76:7211-7220.

15. Nuzzo RG, Zegarski BR, Dubois LH (1987) Fundamental studies of the chemisorption of organosulfur compounds on $\mathrm{Au}(111)$. Implications for molecular self-assembly on gold surfaces. J Am Chem Soc 109:733-740.

16. Nuzzo RG, Dubois LH, Allara DL (1990) Fundamental studies of microscopic wetting on organic surfaces. 1. Formation and structural characterization of a self-consistent series of polyfunctional organic monolayers. J Am Chem Soc 112:558-569.

17. Porter MD, Bright TB, Allara DL, Chidsey CED (1987) Spontaneously organized molecular assemblies. 4. Structural characterization of n-alkyl thiol monolayers on gold by optical ellipsometry, infrared spectroscopy, and electrochemistry. J Am Chem Soc 109:3559-3568.

18. Strong L, Whitesides GM (1988) Structures of self-assembled monolayer films of organosulfur compounds adsorbed on gold single crystals: Electron diffraction studies, Langmuir 4:546-558.

19. Hirata I, Hioki Y, Toda M, Kitazawa T, Murakami Y, Kitano E, Kitamura H, Ikada Y, Iwata H (2003) Deposition of complement protein C3b on mixed self-assembled monolayers carrying surface hydroxyl and methyl groups studied by surface plasmon resonance. J Biomed Mater Res 66A:669-676.

20. Bain CD, Evall J, Whitesides GM (1989) Formation of monolayers by the coadsorption of thiols on gold: Variation in the head group, tail group, and solvent. J Am Chem Soc 111:7155-7164.

21. Arima Y, Iwata H (2007) Effect of wettability and surface functional groups on protein adsorption and cell adhesion using well-defined mixed self-assembled monolayers. Biomaterials 28:3074-3082. 
22. Tarlov MJ, Burgess, Jr. DRF, Gillen G (1993)UV photopatterning of alkanethiolate monolayers self-assembled on gold and silver. J Am Chem Soc 115:5305-5306.

23. Huang J, Dahlgren DA, Hemminger JC (1994) Photopatterning of self-assembled alkanethiolate monolayers on gold: A simple monolayer photoresist utilizing aqueous chemistry. Langmuir 10:626-628.

24. Ryan D, Parviz BA, Linder V, Semetey V, Sia SK, Su J, Mrksich M, Whitesides GM (2004) Patterning multiple aligned self-assembled monolayers using light. Langmuir 20:9080-9088.

25. Kumar A, Biebuyck HA, Whitesides GM (1994) Patterning self-assembled monolayers: Applications in materials science. Langmuir 10:1498-1511.

26. Xia Y, Whitesides GM (1998) Soft lithography. Angew Chem Int Ed Engl 37:550-575.

27. Brockman JM, Frutos AG, Corn RM (1999) A multistep chemical modification procedure to create DNA arrays on gold surfaces for the study of protein-DNA interactions with surface plasmon resonance imaging. J Am Chem Soc 121:8044-8051.

28. Liebermann T, Knoll W (2003) Parallel multispot detection of target hybridization to surfacebound probe oligonucleotides of different base mismatch by surface- plasmon field-enhanced fluorescence microscopy. Langmuir 9:1567-1572.

29. Shumaker-Parry JS, Aebersold R, Campbell CT (2004) Parallel, quantitative measurement of protein binding to a 120 -element double-stranded DNA array in real time using surface plasmon resonance microscopy. Anal Chem 76:2071-2082.

30. Houseman BT, Huh JH, Kron SJ, Mrksich M (2002) Peptide chips for the quantitative evaluation of protein kinase activity. Nature Biotech 20:270-274.

31. Wegner GJ, Lee NJ, Marriott G, Corn RM (2003) Fabrication of histidine-tagged fusion protein arrays for surface plasmon resonance imaging studies of protein-protein and proteinDNA interactions. Anal Chem 75:4740-4746.

32. Houseman BT, Gawalt ES, Mrksich M (2003) Maleimide-functionalized self-assembled monolayers for the preparation of peptide and carbohydrate biochips. Langmuir 19:15221531.

33. Kanda V, Kariuki JK, Harrison DJ, McDermott MT (2004) Label-free reading of microarraybased immunoassays with surface plasmon resonance imaging. Anal Chem 76:7257-7262. 
34. Yamauchi F, Kato K, Iwata H (2004) Micropatterned, self-assembled monolayers for fabrication of transfected cell microarrays. Biochim Biophys Acta 1672:138-147.

35. Yamazoe H, Iwata H (2005) Cell microarray for screening feeder cells for differentiation of embryonic stem cells. J Biosci Bioeng 100:292-296.

36. Ko I-K, Kato K, Iwata H (2005) Parallel analysis of multiple surface markers expressed on rat neural stem cells using antibody microarrays. Biomaterials 26:4882-4891.

37. Kato K, Sato H, Iwata H (2005) Immobilization of histidine-tagged recombinant proteins onto micropatterned surfaces for cell-based functional assays. Langmuir 21:7071-7075.

38. Chen CS, Mrksich M, Huang S, Whitesides GM, Ingber DE (1997) Geometric control of cell life and death. Science 276:1425-1428

39. Brock A, Chang E, Ho CC, LeDuc P, Jiang XY, Whitesides GM, Ingber DE (2003) Geometric determinants of directional cell motility revealed using microcontact printing. Langmuir 19:1611-1617.

40. Lehnert D, Wehrle-Haller B, David C, Weiland U, Ballestrem C, Imhof BA, Bastmeyer M. (2004) Cell behaviour on micropatterned substrata: limits of extracellular matrix geometry for spreading and adhesion. J Cell Sci 117:41-52.

41. McBeath R, Pirone DM, Nelson CM, Bhadriraju K, Chen CS (2004) Cell shape, cytoskeletal tension, and RhoA regulate stem cell lineage commitment. Dev Cell 6:483-95.

42. Arima Y, Iwata H (2007) Effects of surface functional groups on protein adsorption and subsequent cell adhesion using self-assembled monolayers. J Mater Chem 17:4079-4087.

43. Axelrod D, Hellen EH, Fulbright RM (1992) Total internal reflection fluorescence. In: Lakowicz JR (ed) Topics in fluorescence microscopy, Plenum Press, New York.

44. Burmeister JS, Olivier LA, Reichert WM, Truskey GA (1998) Application of total internal reflection fluorescence microscopy to study cell adhesion to biomaterials. Biomaterials $19: 307-325$

45. Tidwell CD, Ertel SI, Ratner BD (1997) Endothelial cell growth and protein adsorption on terminally functionalized, self-assembled monolayers of alkanethiolates on gold. Langmuir 13:3404-3413.

46. Tegoulia VA, Cooper SL (2000) Leukocyte adhesion on model surfaces under flow: Effects of surface chemistry, protein adsorption, and shear rate. J Biomed Mater Res 50:291-301. 
47. McClary KB, Ugarova T, Grainger DW (2000) Modulating fibroblast adhesion, spreading, and proliferation using self-assembled monolayer films of alkylthiolates on gold. J Biomed Mater Res 50:428-439.

48. Franco M, Nealey PF, Campbell S, Teixeira AI, Murphy CJ (2000) Adhesion and proliferation of corneal epithelial cells on self-assembled monolayers. J Biomed Mater Res 52:261269.

49. Scotchford CA, Gilmore CP, Cooper E, Leggett GJ, Downes S (2002) Protein adsorption and human osteoblast-like cell attachment and growth on alkylthiol on gold self-assembled monolayers. J Biomed Mater Res 59:84-99.

50. Faucheux N, Schweiss R, Lützow K, Werner C, Groth T (2004) Self-assembled monolayers with different terminating groups as model substrates for cell adhesion studies. Biomaterials $25: 2721-2730$

51. van Wachem PB, Beugeling T, Feijen J, Bantjes A, Detmers JP, van Aken WG (1985) Interaction of cultured human endothelial cells with polymeric surfaces of different wettabilities. Biomaterials 6:403-408

52. van Wachem PB, Hogt AH, Beugeling T, Feijen J, Bantjes A, Detmers JP, van Aken WG (1987) Adhesion of cultured human endothelial cells onto methacrylate polymers with varying surface wettability and charge. Biomaterials 8:323-328.

53. Tamada Y, Ikada Y (1986) Cell attachment to various polymer surfaces. In: Chiellini E, Giusti P, Migliaresi C, Nicolais L (ed) Polymers in medicine II, Plenum Press, New York.

54. Tamada Y, Ikada Y. (1993) Effect of preadsorbed proteins on cell adhesion to polymer surfaces. J Colloid Interface Sci 155:334-339.

55. Tamada Y, Ikada Y (1993) Cell adhesion to plasma-treated polymer surfaces. Polymer 34:2208-2212.

56. Lee JH, Khang G, Lee JW, Lee HB (1998) Interaction of different types of cells on polymer surfaces with wettability gradient. J Colloid Interface Sci 205: 323-330.

57. Lee JH, Lee JW, Khang G, Lee HB (1997) Interaction of cells on chargeable functional group gradient surfaces. Biomaterials 18:351-358.

58. Sigal GB, Mrksich M, Whitesides GM (1998) Effect of surface wettability on the adsorption of proteins and detergents. J Am Chem Soc 120:3464-3473. 
59. Ostuni E, Chapman RG, Holmlin RE, Takayama S, Whitesides GM (2001) A survey of structure-property relationships of surfaces that resist the adsorption of protein. Langmuir 17:5605.

60. Michael KE, Vernekar VN, Keselowsky BG, Meredith JC, Latour RA, García AJ (2003) Adsorption-induced conformational changes in fibronectin due to interactions with well-defined surface chemistries. Langmuir 19:8033-8040.

61. Arima Y, Toda M, Iwata H Surface plasmon resonance in monitoring of complement activation on biomaterials. Adv Drug Delivery Rev, in press.

62. Lestelius M, Liedberg B, Tengvall P (1997) In vitro plasma protein adsorption on $\square$ functionalized alkanethiolate self-assembled monolayers. Langmuir 13:5900-5908.

63. Prime KL, Whitesides GM (1993) Adsorption of proteins onto surfaces containing endattached oligo(ethylene oxide): A model system using self-assembled monolayers. J Am Chem Soc 115:10714-10721.

64. Evans-Nguyen KM, Schoenfisch MH (2005) Fibrin proliferation at model surfaces: Influence of surface properties. Langmuir 21:1691-1694.

65. Rodahl M, Höök F, Fredriksson C, Keller CA, Krozer A, Brzezinski P, Voinova M, Kasemo B (1997) Simultaneous frequency and dissipation factor QCM measurements of biomolecular adsorption and cell adhesion. Faraday Discuss 107:229-246.

66. Sellborn A, Andersson M, Fant C, Gretzer C, Elwing H (2003) Methods for research on immune complement activation on modified sensor surfaces. Colloids Surf B 27:295-301.

67. Azzam RMA, Bashara NM (1977) Ellipsometry and polarized light. North-Holland Publishing Company, Amsterdam.

68. Knoll W (1991) Polymer thin films and interfaces characterized with evanescent light. Makromol Chem 192:2827-2856.

69. López GP, Albers MW, Schreiber SL, Carroll R, Peralta E, Whitesides GM (1993) Convenient methods for patterning the adhesion of mammalian cells to surfaces using self-assembled monolayers of alkanethiolates on gold. J Am Chem Soc 115:5877-5878.

70. Tegoulia VA, Cooper SL (2000) Leukocyte adhesion on model surfaces under flow: Effects of surface chemistry, protein adsorption, and shear rate. J Biomed Mater Res 50:291-301. 
71. Tegoulia VA, Rao W, Kalambur AT, Rabolt JF, Cooper SL (2001) Surface properties, fibrinogen adsorption, and cellular interactions of a novel phosphorylcholine-containing selfassembled monolayer on gold. Langmuir 17: 4396-4404.

72. Chung YC, Chiu YH, Wu YW, Tao YT (2005) Self-assembled biomimetic monolayers using phospholipid-containing disulfides. Biomaterials 26: 2313-2324.

73. Ostuni E, Chapman RG, Holmlin RE, Takayama S, Whitesides GM (2001) A survey of structure-property relationships of surfaces that resist the adsorption of protein. Langmuir $17: 5605-20$

74. Holmlin RE, Chen X, Chapman RG, Takayama S, Whitesides GM (2001) Zwitterionic SAMs that resist nonspecific adsorption of protein from aqueous buffer. Langmuir 17:284150.

75. Chen S, Yu F, Yu Q, He Y, Jiang S (2006) Strong resistance of a thin crystalline layer of balanced charged groups to protein adsorption. Langmuir 22:8186-91.

76. Pierschbacher MD, Ruoslahti E (1984) Cell attachment activity of fibronectin can be duplicated by small synthetic fragments of the molecule. Nature 309:30-33.

77. Aota S, Nomizu M, Yamada KM (1994) The short amino acid sequence Pro-His-Ser-ArgAsn in human fibronectin enhances cell-adhesive function. J Biol Chem 269: 24756-24761.

78. Toda M, Kitazawa T, Hirata I, Hirano Y, Iwata H (2008) Complement activation on surfaces carrying amino groups. Biomaterials 29:407-417.

79. Cornelius RM, Shankar SP, Brash JL, Babensee JE (2011) Immunoblot analysis of proteins associated with self-assembled monolayer surfaces of defined chemistries. J Biomed Mater Res 98A:7-18.

80. Barrias CC, Martins MCL, Almeida-Porada G, Barbosa MA, Granja PL (2009) The correlation between the adsorption of adhesive proteins and cell behaviour on hydroxyl-methyl mixed self-assembled monolayers. Biomaterials 30:307-316.

81. Keselowsky BG, Collard DM, García AJ (2003) Surface chemistry modulates fibronectin conformation and directs integrin binding and specificity to control cell adhesion. J Biomed Mater Res 66A:247-259.

82. Roberts C, Chen CS, Mrksich M, Martichonok V, Ingber DE, Whitesides GE (1998) Using mixed self-assembled monolayers presenting $\mathrm{RGD}$ and $(\mathrm{EG})_{3} \mathrm{OH}$ groups to characterize long- 
term attachment of bovine capillary endothelial cells to surfaces. J Am Chem Soc 120:65486555.

83. Feng Y, Mrksich M (2004) The synergy peptide PHSRN and the adhesion peptide RGD mediate cell adhesion through a common mechanism. Biochemistry 43: 15811-15821.

84. Orner BP, Derda R, Lewis RL, Thomson JA, Kiessling LL (2004) Arrays for the combinatorial exploration of cell adhesion. J Am Chem Soc 126:10808-10809.

85. Derda R, Li L, Orner BP, Lewis RL, Thomson JA, Kiessling LL (2007) Defined substrates for human embryonic stem cell growth identified from surface arrays. ACS Chem Biol 2:34755.

86. Arnold M, Cavalcanti-Adam EA, Glass R, Blümmel J, Eck W, Kantlehner M, Kessler H, Spatz JP (2004) Activation of integrin function by nanopatterned adhesive interfaces. ChemPhysChem 5:383-388.

87. Nakaji-Hirabayashi T, Kato K, Arima Y, Iwata H (2007) Oriented immobilization of epidermal growth factor onto culture substrates for the selective expansion of neural stem cells. Biomaterials 28:3517-3529

88. Nakaji-Hirabayashi T, Kato K, Iwata H (2008) Essential role of structural integrity and firm attachment of surface-anchored epidermal growth factor in adherent culture of neural stem cells. Biomaterials 29:4403-4408

89. Nakaji-Hirabayashi T, Kato K, Iwata H (2009) Surface-anchoring of spontaneously dimerized epidermal Growth factor for highly selective expansion of neural stem cells. Bioconjugate Chem 20:102-110

90. Konagaya S, Kato K, Nakaji-Hirabayashi T, Iwata H (2011) Design of culture substrates for large-scale expansion of neural stem cells. Biomaterials 32: 992-1001

91. Temple S (2001) The development of neural stem cells. Nature 414:112-117

92. Björklund A, Lindvall O (2000) Cell replacement therapies for central nervous system disorders. Nat Neurosci 3: 537-544

93. Ronaghi M, Erceg S, Moreno-Manzano V, Stojkovic M (2010) Challenges of stem cell therapy for spinal cord injury: Human embryonic stem cells, endogenous neural stem cells, or induced pluripotent stem cells? Stem Cells 28: 93-99 
94. Hermanson GT, Mallia AK, Smith PK (1992) Immobilized affinity ligand techniques. Academic Press, San Diego, CA. pp 57-63

95. Lauer SA, Nolan JP (2002) Development and characterization of Ni-NTA-bearing microspheres. Cytometry 48: 136-145

96. Lu HS, Chai JJ, Li M, Huang BR, He CH, Bi RC (2001) Crystal structure of human epidermal growth factor and its dimerization. J Biol Chem 276: 34913-34917

97. Laibinis PE, Whitesides GM, Allara DL, Tao Y-T, Parikh AN, Nuzzo RG (1991) Comparison of the structures and wetting properties of self-assembled monolayers of n-alkanethiols on the coinage metal surfaces, copper, silver, and gold. J Am Chem Soc 113: 7152-7167

98. Grosdemange GP, Simon ES, Prime KL, Whitesides GM (1991) Formation of self-assembled monolayers by chemisorption of derivatives of oligo(ethylene glycol) of structure $\mathrm{HS}\left(\mathrm{CH}_{2}\right)_{11}\left(\mathrm{OCH}_{2} \mathrm{CH}_{2}\right)_{\mathrm{m}} \mathrm{OH}$ on gold. J Am Chem Soc 113: 12-20

99. Miyamoto K, Yamada P, Yamaguchi RT, Muto T, Hirano A, Kimura Y, Niwano M, Isoda H (2007) In situ observation of a cell adhesion and metabolism using surface infrared spectroscopy. Cytotechnology 55: 143-149

100. Ullrich A, Schlessinger J (1990) Signal transduction by receptors with tyrosine kinase activity. Cell 61: 203-212

101. Tripet B, Wagschal K, Lavigne P, Mant CT, Hodges RS (2000) Effects of side-chain characteristics on stability and oligomerization state of a de Novo-designed model coiled-coil: 20 amino acid substitutions in position "d". J Mol Biol 300: 377-402

102. Ogiso H, Ishitani R, Nureki O, Fukai S, Yamanaka M, Kim J-H, Saito K, Sakamoto A, Inoue M, Shirouzu M, Yokoyama S (2002) Crystal structure of the complex of human epidermal growth factor and receptor extracellular domains. Cell 110: 775-787

103. Kumada Y, Shiritani Y, Hamasaki K, Ohse T, Kishimoto M. (2009) High biological activity of a recombinant protein immobilized onto polystyrene. Biotechnol J 4: 1178-1189

104. Contreras Jl, Xie D, Mays J et al. (2004) A novel approach to xenotransplantation combining surface engineering and genetic modification of isolated adult porcine islets. Surgery $136: 537-547$

105. Hashemi-Najafabadi S, Vasheghani-Farahani E, Shojaosadati SA et al. (2006) A method to optimize PEG-coating of red blood cells. Bioconjug Chem 17:1288-1293 
106. Nacharaju P, Boctor FN, Manjula BN et al. (2005) Surface decoration of red blood cells with maleimidophenyl-polyethylene glycol facilitated by thiolation with iminothiolane: an approach to mask A, B, and D antigens to generate universal red blood cells. Transfusion $45: 374-383$

107. Scott MD, Murad KL, Koumpouras F et al. (1997) Chemical camouflage of antigenic determinants: stealth erythrocytes. Proc Natl Acad Sci USA 94:7566-7571

108. Elbert DL, Herbert CB, Hubbell JA (1999) Thin polymer layers formed by polyelectrolyte multilayer techniques on biological surfaces. Langmuir 15:5355-5362

109. Germain M, Balaguer P, Nicolas Jc et al. (2006) Protection of mammalian cell used in biosensors by coating with a polyelectrolyte shell. Biosensors \& Bioelectronics 21:1566-1573

110. Krol S, Del Guerra S, Grupillo M et al. (2006) Multilayer nanoencapsulation. New approach for immune protection of human pancreatic islets. Nano Lett 6:1933-1939

111. Veerabadran Ng, Goli Pl, Stewart-Clark Ss et al. (2007) Nanoencapsulation of stem cells within polyelectrolyte multilayer shells. Macromol Biosci 7:877-882

112. Chen H, Teramura Y, Iwata H (2011) Co-immobilization of urokinase and thrombomodulin on islet surfaces by poly(ethylene glycol)-conjugated phospholipid. J Control Release $150: 229-234$

113. Inui O, Teramura Y, Iwata H (2010) Retention dynamics of amphiphilic polymers PEGlipids and PVA-Alkyl on the cell surface. ACS Appl Mater Interfaces 2:1514-1520

114. Luan NM, Teramura Y, Iwata H (2011) Immobilization of soluble complement receptor 1 on islets. Biomaterials 32:4539-4545

115. Miura S, Teramura Y, Iwata H (2006) Encapsulation of islets with ultra-thin polyion complex membrane through poly(ethylene glycol)-phospholipids anchored to cell membrane. Biomaterials $27: 5828-5835$

116. Sakurai K, Teramura Y, Iwata H (2011) Cells immobilized on patterns printed in DNA by an inkjet printer. Biomaterials 32:3596-3602

117. Takemoto N, Teramura Y, Iwata H (2011) Islet surface modification with urokinase through DNA hybridization. Bioconjug Chem 22:673-678

118. Teramura $Y$, Chen $H$, Kawamoto $T$ et al. (2010) Control of cell attachment through polyDNA hybridization. Biomaterials 31:2229-2235 
119. Teramura Y, Iwata H (2010) Bioartificial pancreas microencapsulation and conformal coating of islet of Langerhans. Adv Drug Deliv Rev 62:827-840

120. Teramura Y, Iwata H (2010) Cell surface modification with polymers for biomedical studies. Soft Matter 6:1081-1091

121. Teramura Y, Iwata H (2011) Improvement of graft survival by surface modification with poly(ethylene glycol)-lipid and urokinase in intraportal islet transplantation. Transplantation 91:271-278

122. Teramura Y, Iwata H (2009) Islet encapsulation with living cells for improvement of biocompatibility. Biomaterials 30:2270-2275

123. Teramura Y, Iwata H (2008) Islets surface modification prevents blood-mediated inflammatory responses. Bioconjug Chem 19:1389-1395

124. Teramura Y, Iwata H (2009) Surface modification of islets with PEG-lipid for improvement of graft survival in intraportal transplantation. Transplantation 88:624-630

125. Teramura Y, Kaneda Y, Iwata H (2007) Islet-encapsulation in ultra-thin layer-by-layer membranes of poly(vinyl alcohol) anchored to poly(ethylene glycol)-lipids in the cell membrane. Biomaterials 28:4818-4825

126. Teramura Y, Kaneda Y, Totani T et al. (2008) Behavior of synthetic polymers immobilized on a cell membrane. Biomaterials 29:1345-1355

127. Teramura Y, Minh Ln, Kawamoto T et al. (2010) Microencapsulation of islets with living cells using polyDNA-PEG-lipid conjugate. Bioconjug Chem 21:792-796

128. Totani T, Teramura Y, Iwata H (2008) Immobilization of urokinase on the islet surface by amphiphilic poly(vinyl alcohol) that carries alkyl side chains. Biomaterials 29:2878-2883

129. Bennet W, Sundberg B, Groth Cg et al. (1999) Incompatibility between human blood and isolated islets of Langerhans: a finding with implications for clinical intraportal islet transplantation? Diabetes 48:1907-1914

130. Moberg L, Johansson H, Lukinius A et al. (2002) Production of tissue factor by pancreatic islet cells as a trigger of detrimental thrombotic reactions in clinical islet transplantation. Lancet 360:2039-2045

131. Nilsson B, Korsgren O, Lambris Jd et al. (2010) Can cells and biomaterials in therapeutic medicine be shielded from innate immune recognition? Trends Immunol 31:32-38 
Table 1. Proliferation of neurosphere-forming cells in cultures with or without EGF-immobilized surfaces

\begin{tabular}{lllll}
\hline $\begin{array}{l}\text { COOH-thiol } \\
\begin{array}{l}\text { content } \\
(\%)\end{array}\end{array}$ & $\begin{array}{l}\text { Surface density } \\
\text { of EGF-His } \\
\left(\mathrm{ng} / \mathrm{cm}^{\mathrm{b}}\right)\end{array}$ & $\begin{array}{l}\text { Cell number } \\
\left.{\text { after } 24 \mathrm{~h}^{\mathrm{c}}}^{\mathrm{a}} \times 10^{4} \mathrm{cells} / \mathrm{cm}^{2}\right)\end{array}$ & $\begin{array}{l}\text { Cell number } \\
\text { after } 5 \mathrm{days} \mathrm{c}^{\mathrm{c}} \\
\left(\times 10^{4} \mathrm{cells} / \mathrm{cm}^{2}\right)\end{array}$ & $\begin{array}{l}\text { Doubling } \\
\text { time }^{\mathrm{d}} \\
(\mathrm{h})\end{array}$ \\
\hline 0 & 51 & $0.7 \pm 0.3$ & $11.7 \pm 5.1$ & n.d. \\
0.01 & 76 & $1.2 \pm 0.4$ & $38.6 \pm 17.6$ & $16.8 \pm 5.5$ \\
0.1 & 110 & $1.4 \pm 0.2$ & $46.4 \pm 17.2$ & $16.7 \pm 5.2$ \\
1 & 215 & $1.6 \pm 0.1$ & $49.6 \pm 15.2$ & $17.2 \pm 5.4$ \\
10 & 342 & $1.8 \pm 0.2$ & $56.7 \pm 10.5$ & $17.3 \pm 5.9$ \\
100 & 390 & $2.5 \pm 0.2$ & $64.0 \pm 6.6$ & $17.0 \pm 4.0$ \\
\hline Neurosphere & - & - & - & $31.2 \pm 1.4^{\mathrm{e}}$ \\
\hline
\end{tabular}

${ }^{\mathrm{a}}$ Content in the solution used to prepare the mixed SAMs. ${ }^{\mathrm{b}}$ Determined with a microBCA assay.

${ }^{\mathrm{c}}$ Mean \pm standard deviation for $\mathrm{n}=5$ assays. ${ }^{\mathrm{d}}$ Determined from the logarithmic plot of growth curves for the culture period of 24-72 $\mathrm{h}$. Mean \pm standard deviation for $\mathrm{n}=4$ assays.

${ }^{\mathrm{e}}$ Determined for cells during the standard neurosphere culture. Reproduced from Nakaji-

Hirabayashi, T., et al. 2007 [87] with permission from Elsevier (C2007. 
Figure captions

(a)
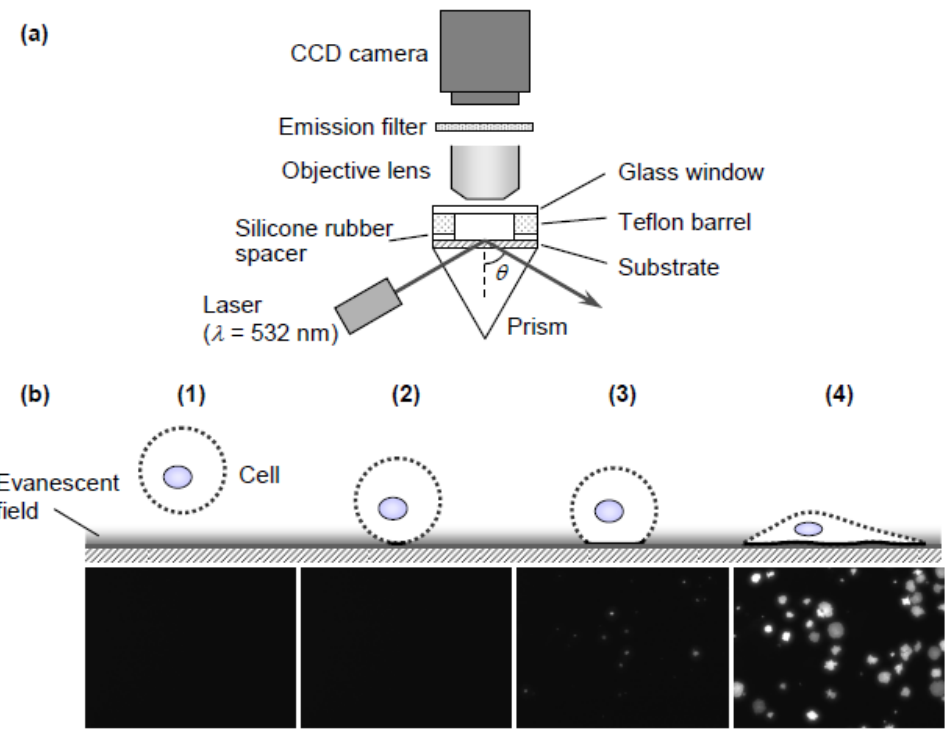

Fig. 1. Real-time tracking of cell adhesion. (a) Components of a total internal reflection fluorescent microscope (TIRFM); (b, top) A model of the cell adhesion process [42]. The evanescent field was generated by total internal reflection of a laser beam at the glass/water interface. Cells with fluorescently labeled membranes (dashed lines) were plated on SAMs. Cell membranes within the evanescent field (solid line) were observed by TIRFM. (b, bottom) Corresponding TIRFM images; (b-1) a cell approaches the surface; (b-2) the cell is landing; (b-3) the cell attaches, and (b-4) the cell spreads out on the surface. 


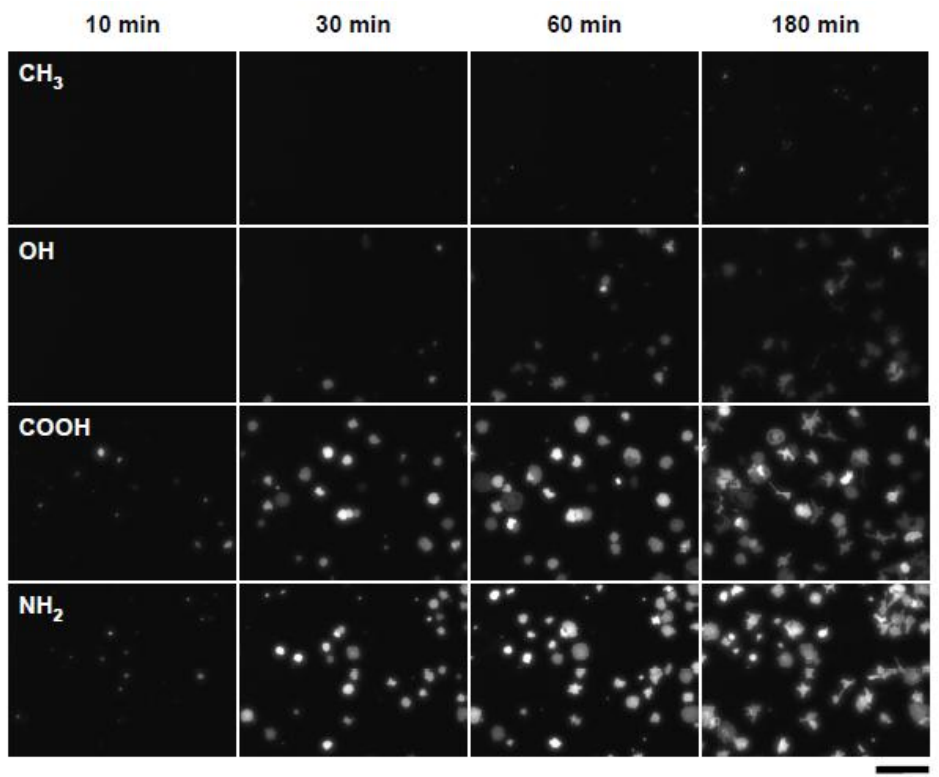

Fig. 2. TIRFM images of HUVEC adhesion behavior on SAMs with four different types of surface functional groups. (Top) Time after first applying cell suspension. Scale bar: $200 \mu \mathrm{m}$. [42] 

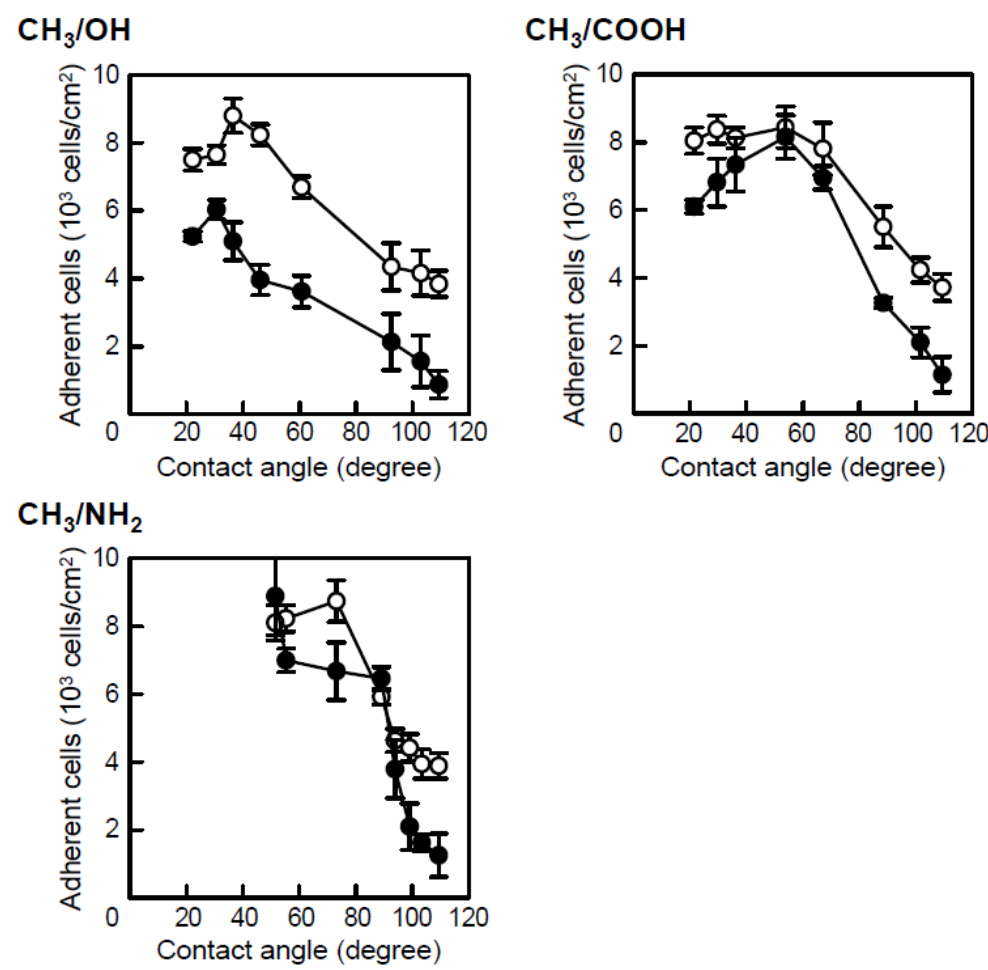

Fig. 3. Relationship between water contact angles on mixed SAMs and the number of adherent cells. HUVECs $(\circ)$ and HeLa cells $(\bullet)$ were allowed to adhere for $1 \mathrm{~h}$. The averages (SEM) of five experiments are shown [21]. 
(a)

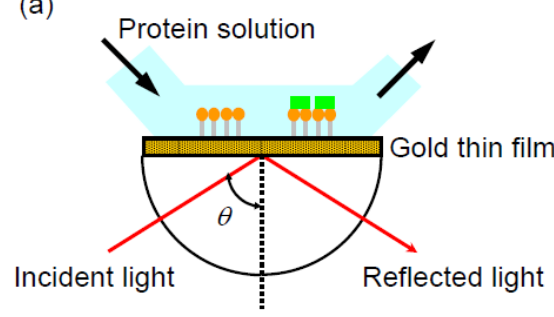

(c)

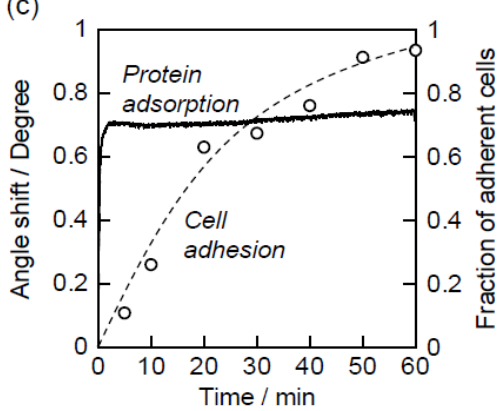

(b)

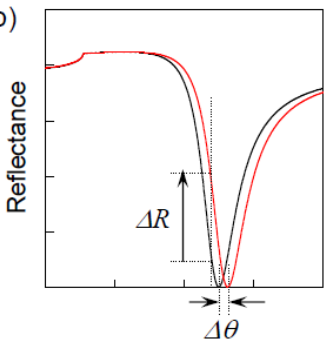

Incident angle

$\left.\begin{array}{ll}\text { Serum proteins } & \text { Concentration } \\ \hline \text { Albumin } & 35-50 \mathrm{mg} / \mathrm{mL} \\ \text { IgG } & 8-18 \mathrm{mg} / \mathrm{mL} \\ \vdots & \\ \text { Vitronectin } & 200 \mu \mathrm{g} / \mathrm{mL} \\ \text { Fibronectin } & 30 \mu \mathrm{g} / \mathrm{mL}\end{array}\right] \begin{aligned} & \text { Cell adhesive } \\ & \text { proteins }\end{aligned}$

Fig. 4. The effect of proteins on cell adhesion. (a) Schematic illustration of the Kretschmann configuration for SPR. (b) Reflectance as a function of incident angle, before (black) and after (red) the adsorption of substances. (c, left) Time course of SPR angle shift during exposure to culture medium supplemented with 2\% FBS (solid line) and the fraction of adherent cells determined by TIRFM (circles) on $\mathrm{NH}_{2}$-SAM. The dashed line is a manual fit to the symbols, included simply as a guide [42]. (c, right) The concentrations of serum proteins in FBS. 

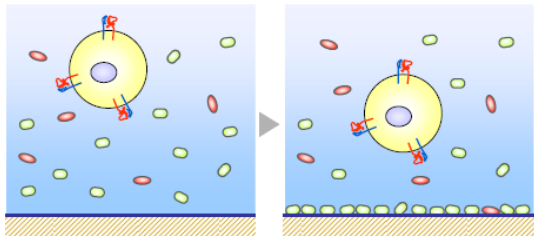

Protein adsorption
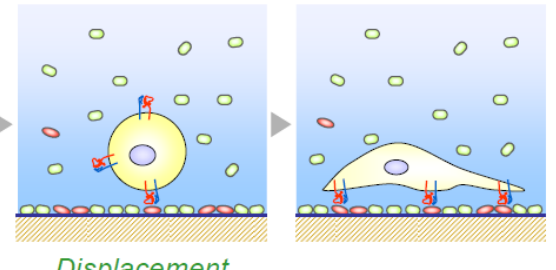

$\circ:$ Cell non-adhesive proteins

(ex. Albumin, lgG)

$\circ:$ Cell adhesive proteins

(fibronectin, vitronectin)

b) : Integrin

Fig. 5. Schematic representation of cell adhesion to a material surface, including the adsorption of serum proteins.

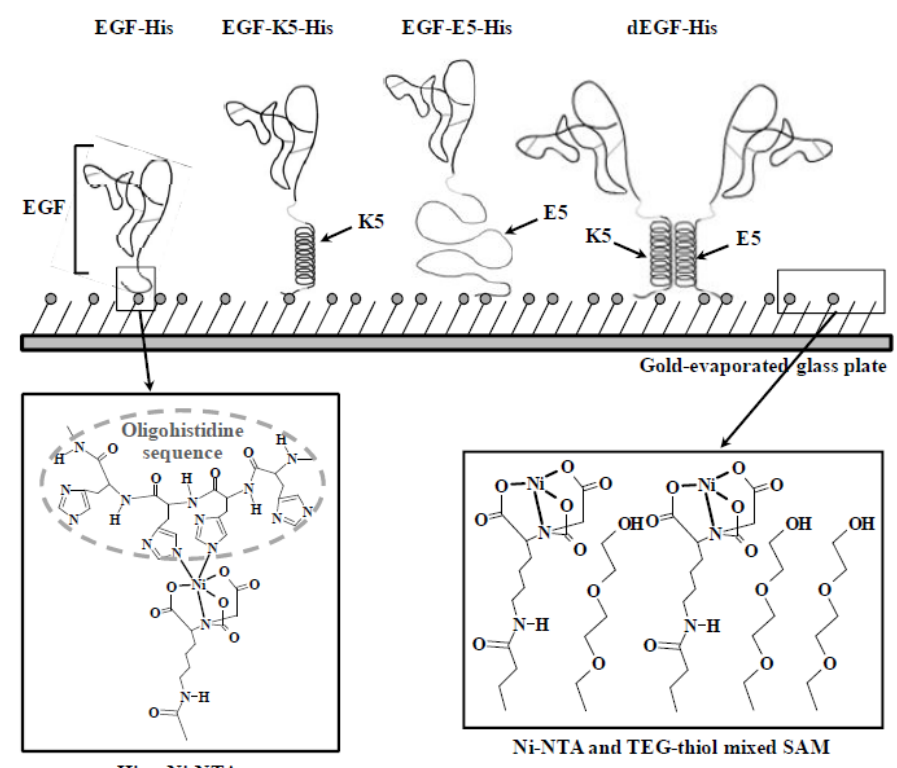

Fig. 6. Schematic representation of EGF-containing chimeric proteins anchored to the Ni-

chelated surface through coordination. Bold lines in the molecular structures represent chelate bonding. TEG-thiol: triethylene glycol-containing alkanethiol. Reproduced from NakajiHirabayashi, T., et al. 2009 [89] with permission from American Chemical Society (C2009. 


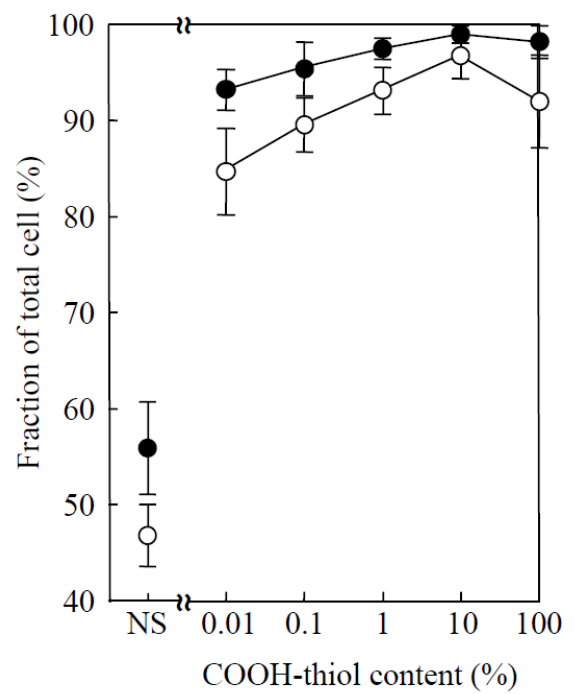

Fig. 7. Quantitative evaluation of NSC enrichments in cultures with different material surfaces. The fraction of NSC phenotypes in the cultures are shown for (open circles) nestin ${ }^{+} \beta \mathrm{III}^{-}$ or (closed circles) both nestin ${ }^{+} \beta \mathrm{III}^{-}$and nestin ${ }^{+} \beta \mathrm{III}^{+}$. Data are also shown for neurosphere cultures (NS). The averages (SEM) of five experiments are shown. Reproduced from NakajiHirabayashi, T., et al. 2007 [87] with permission from Elsevier (C2007. 
(a) Surface modification with ssDNA-PEG-lipid

(a) -1

(a)-2
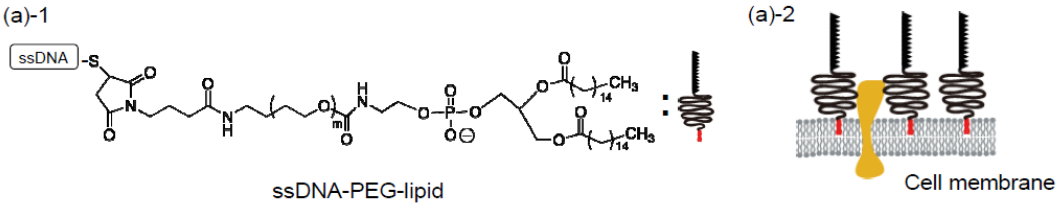

(b) Introduction of SSDNA' on protein

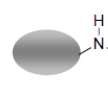

maleimide-protein
$\mathrm{SH}-\mathrm{ssDNA} \longrightarrow$

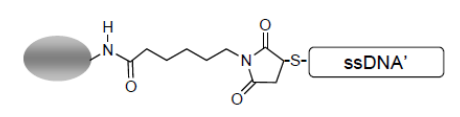

ssDNA'-protein

(c)

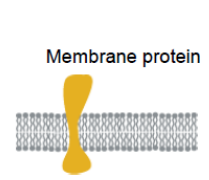

Cell membrane
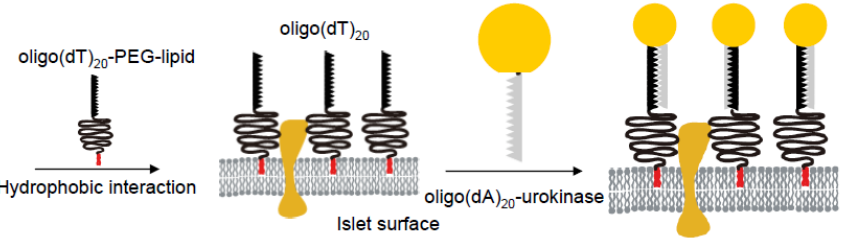

Fig. 8. Immobilization of urokinase protein on the surfaces of islet cells. (a-1) Chemical structure of DNA-conjugated PEG-phospholipid (DNA-PEG-lipid); (a-2) ssDNA-PEG-lipid anchoring to the cell membrane. (b) Introduction of a complementary ssDNA onto urokinase protein, which was first modified with a madeimide group by EMCS. (c) Schematic representation of urokinase-immobilization through DNA hybridization [117]. 
(a)

(i) Formation of supported lipid membrane (ii) Incorporation of PEG-lipids (100 mg/mL)

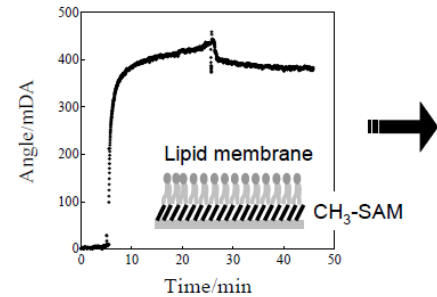

(b)

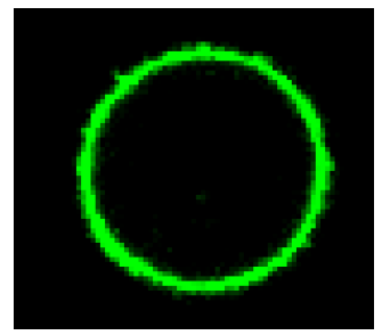

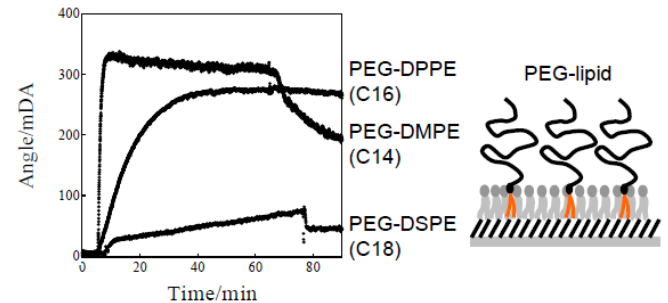

(c)

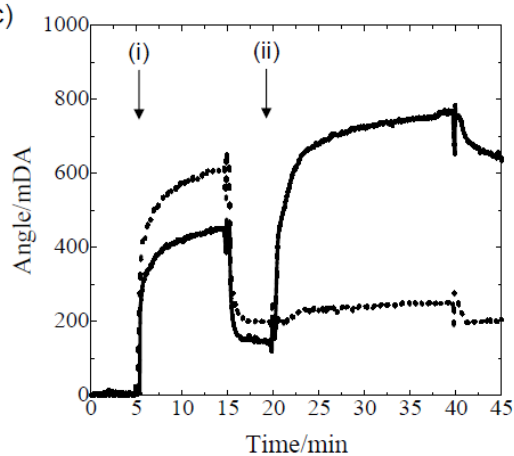

Fig. 9. Surface modification of cells with DNA-PEG-lipid [120]. (a) Real-time monitoring of PEG-lipid incorporation into a supported lipid membrane by surface plasmon resonance (SPR).

(i) A suspension of small, unilamellar vesicles of egg yolk lecithin $(70 \mu \mathrm{g} / \mathrm{mL})$ was applied to a methyl-terminated self-assembly monolayer $\left(\mathrm{CH}_{3}\right.$-SAM) surface. A PEG-lipid solution (100 $\mu \mathrm{g} / \mathrm{mL}$ ) was then applied. (ii) Three types of PEG-lipids were compared: PEG-DMPE (C14), PEG-DPPE (C16), and PEG-DSPE (C18) with acyl chains of 14, 16, and 18 carbons, respectively. (b) Confocal laser scanning microscopic image of an CCRF-CEM cell displays immobilized FITC-oligo(dA) $)_{20}$ hybridized to membrane-incorporated oligo(dT) $)_{20}-$ PEG-lipid. (c) SPR sensorigrams of interaction between oligo $(\mathrm{dA})_{20}$-urokinase and the oligo $(\mathrm{dT})_{20}$-PEG-lipid incorporated into the cell surface. (i) A BSA solution was applied to block non-specific sites on the oligo(dT) $)_{20}$-incorporated substrate; (ii) oligo(dA) $)_{20}$-urokinase (solid line) or oligo(dT) ${ }_{20}$ urokinase (dotted line) was applied. 
(a)
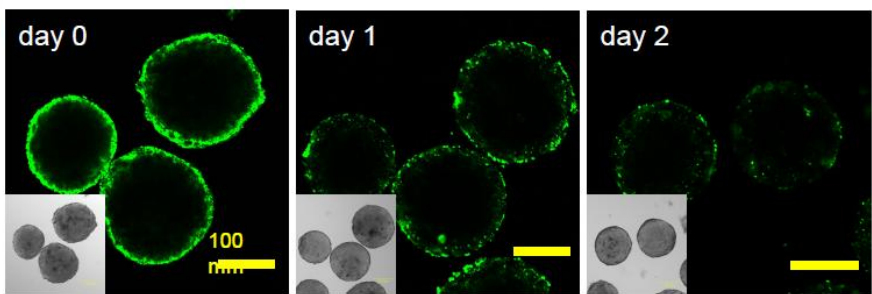

(b)
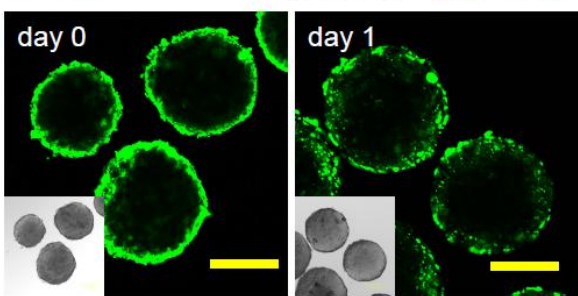

(c)

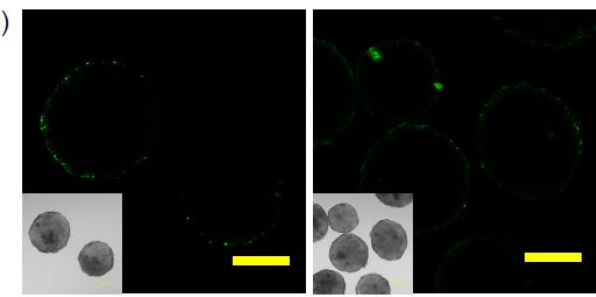

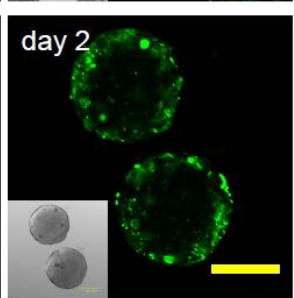

Fig. 10. Confocal laser scanning microscope images of islets with urokinase (UK) immobilized on the membrane [117]. The green signal indicates positive immunostaining for UK. (a) Islets were modified with oligo(dT) ${ }_{20}-\mathrm{PEG}$-lipid (C16) or (b) oligo(dT) ${ }_{20}-\mathrm{PEG}-$ lipid (C18); then, oligo(dA) $)_{20}-\mathrm{UK}$ was added to the media. (c) Unmodified islets, with (left) and without oligo(dT) ${ }_{20}-$ PEG-lipids added to the solution. Insets: Phase contrast microscopic images. Scale bar: $100 \mu \mathrm{m}$. 
(a)

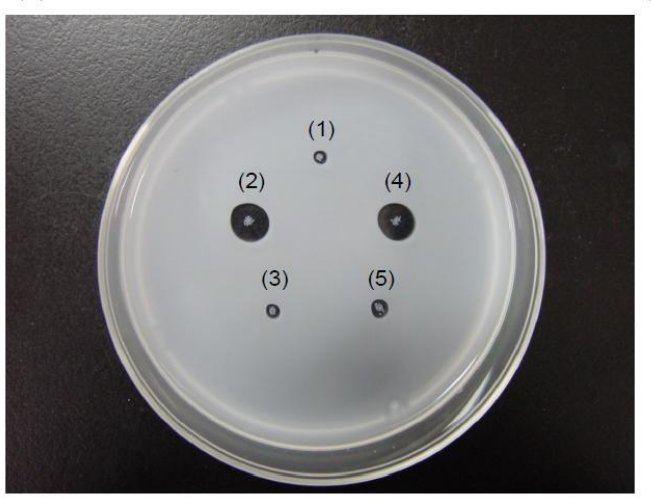

(b)

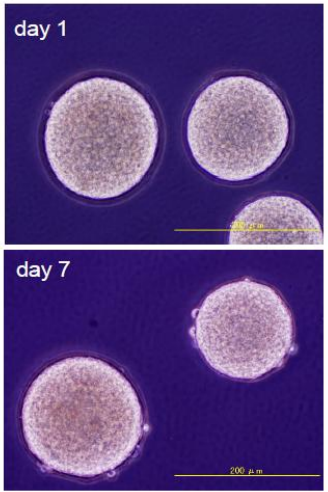

Fig. 11. Islets with immobilized urokinase (UK-islets) were tested for the ability to dissolve fibrin [117]. (a) Fibrin in the plate gel medium was dissolved by UK-islets (clear areas). Fifty islets were applied to each spot, and the plate was observed after incubation at $37^{\circ} \mathrm{C}$ for $14 \mathrm{~h}$. (1) untreated islets; (2) UK-islets (with oligo(dT) ${ }_{20}-\mathrm{PEG}-$ lipid (C16)), just after preparation; (3) UKislets (with oligo(dT) ${ }_{20}-\mathrm{PEG}$-lipid (C16)) lost activity after 2 days in culture; (4) UK-islets (with oligo(dT) $)_{20}-$ PEG-lipid (C18)), just after preparation; and (5) UK-islets (with oligo(dT) $)_{20}-$ PEGlipid (C16)) lost activity after 2 days in culture. (b) Morphology of UK-islets after 1day and 7 days of culture. 
(a)

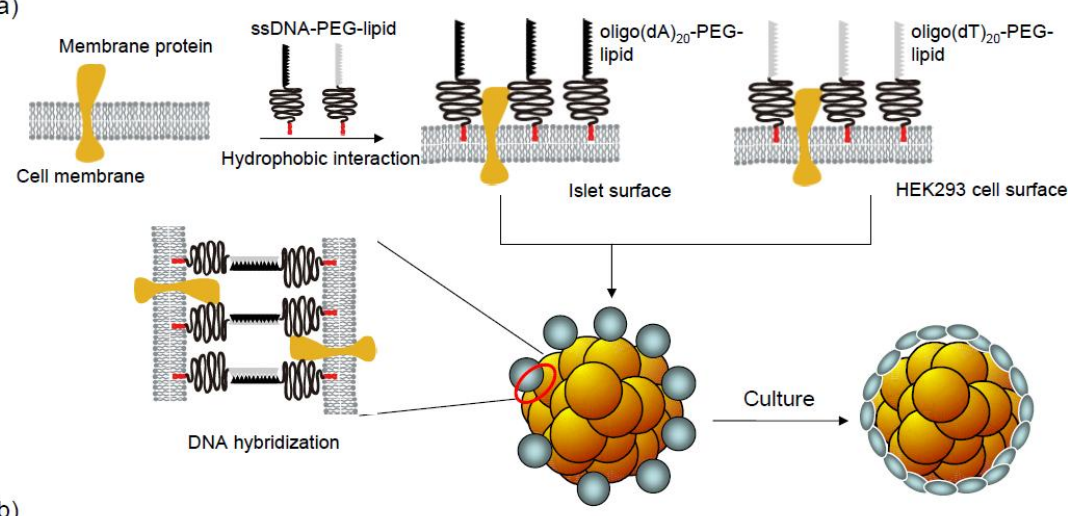

(b)

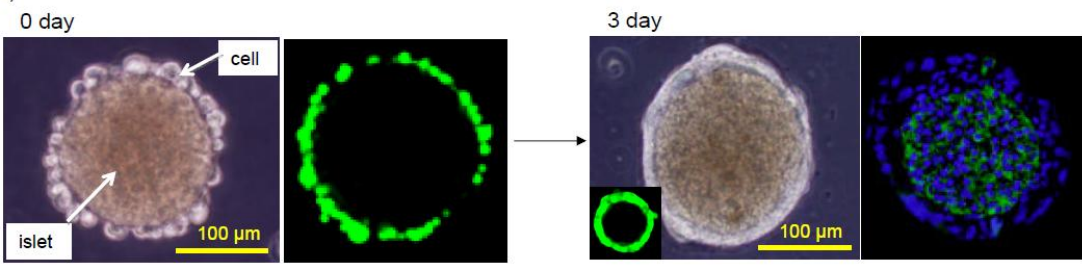

Fig. 12. Islet encapsulation within living HEK293 cells that express green fluorescent pro-

tein (GFP) [127]. (a) Schematic illustration. Islets are enclosed within a capsule of HEK293 cells (that express GFP) by introducing surface modifications of complementary single-stranded DNAs. Islets modified with oligo(dT) ${ }_{20}$-PEG-lipid are combined with HEK293 cells that have oligo(dA) $)_{20}$-PEG-lipid immobilized on the surface. DNA hybridization immobilizes the HEK293 cells to the surface of the islets. After 3 days in culture, islets are completely encapsulated within HEK293 cells. (b) Phase contrast (left panels) and fluorescence images (right panels) of islets with attached HEK293 cells. (0 days) GFP-HEK cells immobilized to islets observed with a confocal laser-scanning microscope; (3 days) Frozen sections of islets with attached GFP-HEK cells were stained with Alexa 488-labeled anti-insulin antibody (green) and Hoechst 33342 dye (blue) for nuclear staining. 